Timo J. Ruokonen1, Timo J. Marjomäki1, Iia Suomi1, Tero Forsman², Tapio Keskinen ${ }^{3}$ \& Juha Karjalainen ${ }^{1}$

1)Jyväskylän yliopisto, bio- ja ympäristötieteiden laitos, luonnonvarat ja ympäristö, 2)Pyhäjärvi-instituutti, ${ }^{3}$ Luonnonvarakeskus, Jyväskylä

\title{
Sisävesien talouslajien saalispotentiaali Suomessa
}
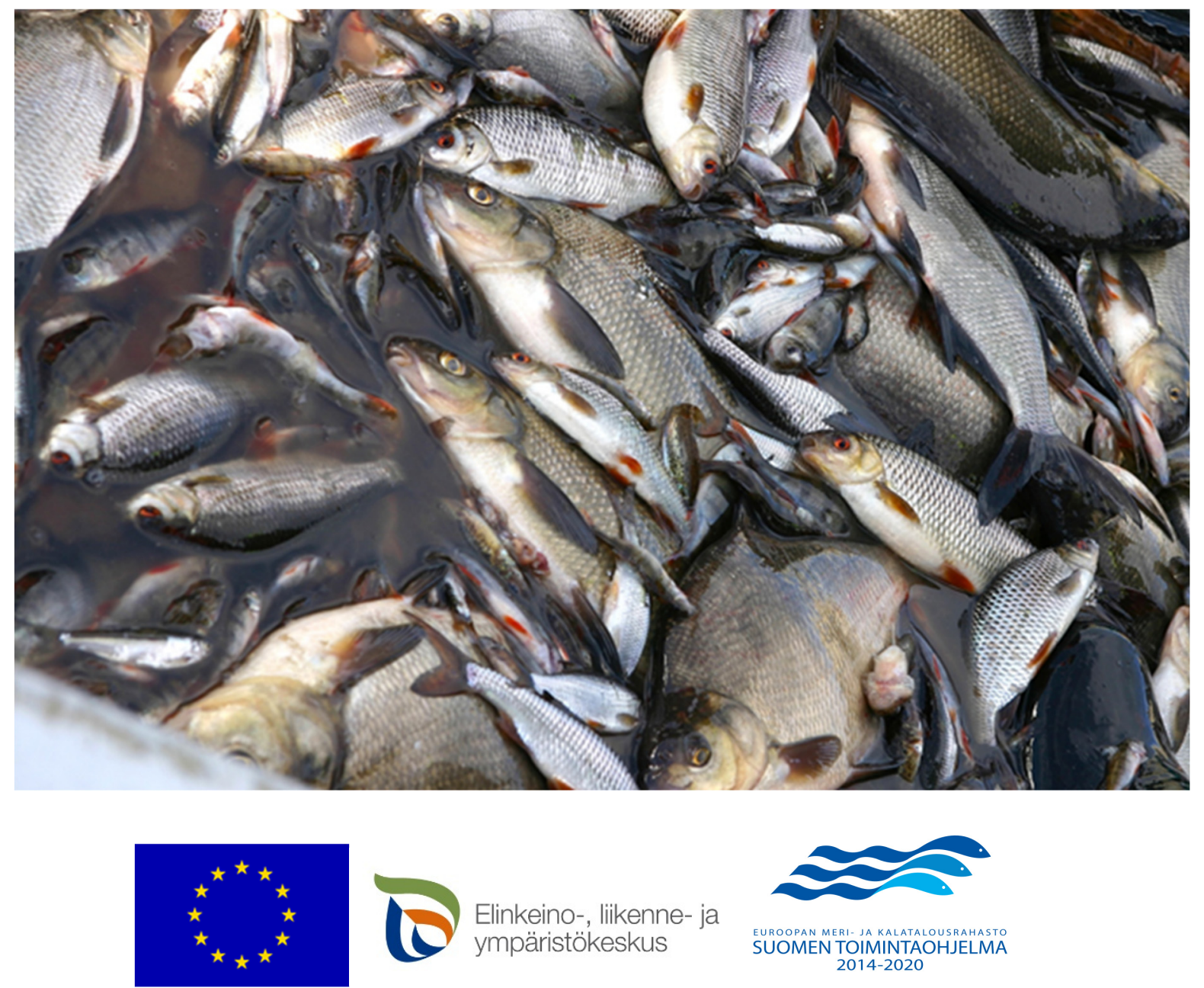

EUROOPAN MERI- JA KALATALOUSRAHASTO
SUOMEN TOIMINTAOHJELMA 2014-2020

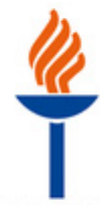


Jyväskylän yliopiston bio- ja ympäristötieteiden laitoksen tiedonantoja / Proceedings of the Department of Biological and Environmental Science, University of Jyväskylä

Toimittaja / Editor: Timo J. Marjomäki

Kansikuva / Cover photo: Tapio Keskinen

ISSN 2669-8986

ISBN 978-951-39-7866-2 (PDF)

Julkaisun pysyvä osoite / Permanent address to this publication:

http:// urn.fi/URN:ISBN:978-951-39-7866-2

Jyväskylä 2019 


\section{TIIVISTELMÄ}

Ruokonen, Timo, Marjomäki, Timo J., Suomi, Iia, Forsman, Tero, Keskinen, Tapio \& Karjalainen, Juha

Sisävesien talouslajien saalispotentiaali Suomessa

Jyväskylä: Jyväskylän yliopisto, 2019, 32 s. + 2 liitettä.

Jyväskylän yliopiston bio- ja ympäristötieteiden laitoksen tiedonantoja 3/2019 ISSN 2669-8986

ISBN 978-951-39-7866-2 (PDF)

Sisävesien talouslajien ekologisesti kestävä saalispotentiaali -hankkeessa selvitettiin vajaasti hyödynnettyjen kalavarojen arvioinnin tietotarpeita, kehitettiin arvioinnin tieteellistä perustaa sekä arvioitiin särjen ja ahvenen saalispotentiaali Suomen järvissä. Hanke toteutettiin yhteistyössä kaupallisten kalastajien, Luonnonvarakeskuksen ja Pyhäjärvi-instituutin kanssa. Kalastajilta hankittiin kalastustilastoja, ja heidän näkemyksiään vajaasti hyödynnettyjen kalalajien pyynnistä ja saalispotentiaalista selvitettiin haastatteluin. Erillisellä haastattelulla selvitettiin Säkylän Pyhäjärven kalastajien näkemyksiä.

Hoitokalastussaaliiden sopivuutta elintarvikkeeksi selvitettiin jalostajien haastattelulla. Särjen ja ahvenen saalispotentiaaliarvioiden pohjatiedoiksi koottiin tiedot hoitokalastushankkeiden pyyntiponnistuksesta ja saaliista, aiemmat saalispotentiaaliarviot sekä tutkimustulokset erilaisten vesistöjen kalatuotannosta ja siihen vaikuttavista tekijöistä. Suomi jaettiin kolmeen alueeseen (Etelä- ja "Keski-Suomi", Pohjois-Pohjanmaa ja Kainuu, Lappi), joiden kalatuotantopotentiaalin arvioitiin poikkeavan toisistaan. Järvet jaettiin alueittain kolmeen tyyppiin (isot karut/karuhkot, keskikokoiset ja pienet karut/karuhkot, keskikokoiset ja pienet rehevät). Suomen sisävesien särkisaalispotentiaali on 80 \% todennäköisyydellä välillä 12-26 Mkg/vuosi (M = miljoona) ja paras arvio noin $19 \mathrm{Mkg}$. Ahvenen saalispotentiaali on vastaavasti 6-12 Mkg/vuosi ja paras arvio noin $9 \mathrm{Mkg}$.

Saalispotentiaali/hehtaari arvioitiin suurimmaksi Etelä- ja "Keski-Suomen" rehevissä järvissä ja pienimmäksi isoissa ja keskikokoisissa karuissa järvissä. Potentiaali pienenee pohjoiseen päin mentäessä. Haastateltujen kalastajien kokemusten perusteella särkikalojen pyynti elintarvikkeeksi voi olla kannattavaa yhdellä vähintään 1000 ha tai useammalla muutaman sadan hehtaarin järvellä. Kalastajilla on käytössään pyyntiin tarvittava tietotaito ja tehokkaat kalastusmenetelmät. Elintarvikepyynnin kannalta ongelmallisia ovat isot, lajittelua vaativat sekakalasaaliit ja sopivan kokoisten kalojen pieni määrä. Järvien välinen vaihtelu elintarvikkeeksi kelpaavan kalan osuudessa on suurta. Kalastajat toivovat tarkempia järvikohtaisia arvioita erityisesti särkikalakantojen tilasta. Näiden tietojen avulla kalastukseen soveltuvien järvien tunnistus onnistuisi etukäteen ja kokeilujen tekeminen sopivissa kohteissa helpottuisi lyhyiden sesonkien aikana.

Hakusanat: ahven; kalastaja; kestävä kalastus; saalispotentiaali; särkikalat. 


\begin{abstract}
Ruokonen, Timo, Marjomäki, Timo J., Suomi, Iia, Forsman, Tero, Keskinen, Tapio \& Karjalainen, Juha

Maximum sustainable yield of roach and perch in Finnish lakes

Jyväskylä: University of Jyväskylä, 2019, 32 p. + 2 appendices.

Proceedings of the department of biological and environmental science,

University of Jyväskylä 3/2019.

ISSN 2669-8986

ISBN 978-951-39-7866-2 (PDF)
\end{abstract}

In the project Ecologically sustainable potential yield of commercially important inland fishes, the information requirements for stock assessment of weakly exploited inland fish stocks were listed, the assessment methods developed and maximum sustainable yield (MSY) of roach (Rutilus rutilus) and perch (Perca fluviatilis) estimated in Finnish lakes. The project was carried out in cooperation with commercial fishers, Natural Resources Institute Finland and Pyhäjärvi institute. Fishers provided for fishing statistics. Their views of fishing and sustainable yield of weakly exploited fishes were collected by personal interviews. A separate questionnaire was used for fishers in Lake Säkylän Pyhäjärvi. The suitability of yields of biomanipulation projects for food production was assessed by interviewing the fish processors. The background data for MSY estimates consisted of information on effort and yield from biomanipulation projects, previous MSY estimates and data from scientific analyses of lake fish production and the factors affecting it. The MSY of roach and perch were estimated based on these data. Based on the estimated fish production potential, Finland was divided into three geographical zones and the lakes in three classes based on their size and productivity. The MSY of roach in Finnish lakes is with $80 \%$ credibility 12-26 million $\mathrm{kg}$ /annum, best estimate being about $19 \mathrm{Mkg} / \mathrm{a}$. The estimates for perch are 6-12 Mkg/a and $9 \mathrm{Mkg} / \mathrm{a}$, respectively. The MSY/ha was estimated to be highest in oligotrophic lakes in Southern and Central Finland and lowest in large oligotrophic lakes. The MSY declines with increase in northern latitude. The commercial fishers consider that fishing of cyprinid fishes for food processing may be profitable in a single at minimum 1000 ha lake or several lakes of a few hundreds of ha in area. Yet, the proportion of yield suitable for processing varies largely between lakes. The fishers consider that they possess the required know-how and efficient techniques for commercial fishing. The largest challenges stem from large multispecies catches requiring sorting and small amount of fish of suitable size for processing. The fishers consider that they would benefit from more accurate lake-specific assessment of cyprinid fish stocks. This would facilitate the identification of suitable fishing sites in advance and experimenting in these sites during short fishing season.

Keywords: perch; fisher; sustainable fishing; potential yield; cyprinid. 


\section{SISÄLTÖ}

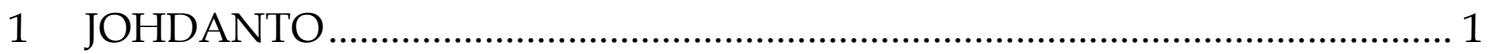

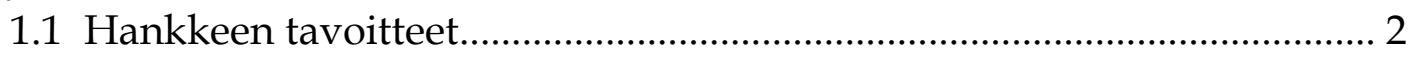

1.2 Hankkeen yhteistyötahot ja keskeiset sidosryhmät................................ 2

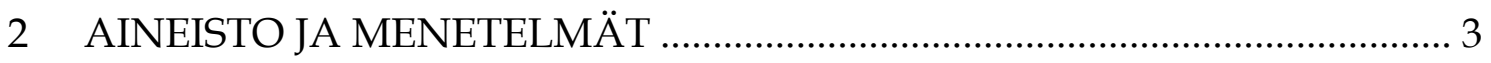

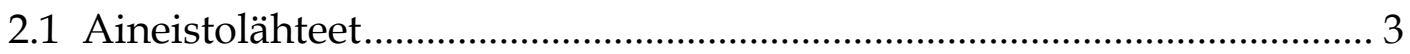

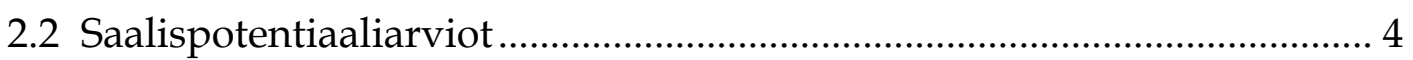

2.1.1 Järvien luokittelu tuotantopotentiaalin mukaisesti........................ 4

2.2.2 Biomassa-, tuotanto- ja saalispotentiaaliarviot, kestävyys .............. 5

2.3 Kalastajakump panien haastattelut ..................................................... 7

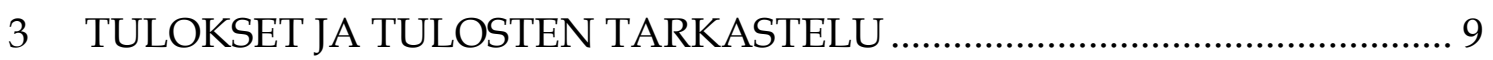

3.1 Kaupallisten ja vapaa-ajan kalastajien saaliit......................................... 9

3.2 Hoitokalastuskohteet, saaliit ja eri lajien saalisosuudet .......................... 10

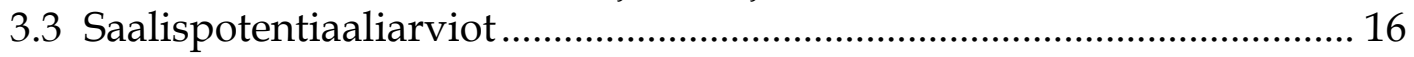

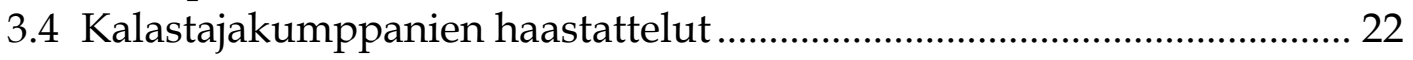

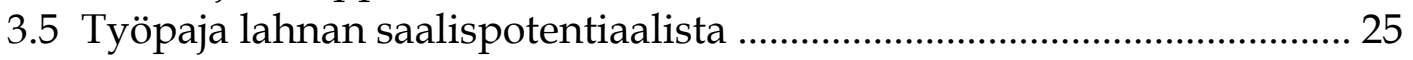

3.6 Säkylän Pyhäjärvi - kalastajahaastattelut .............................................. 27

3.7 Hoitokalastussaaliiden hyödynnettävyys elintarvikkeena..................... 28

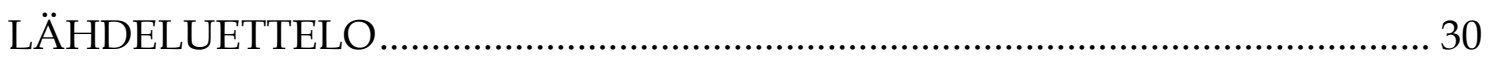

\section{LIITTEET}

Liite 1. Kalastajakumppanien haastatteluissa käytetty haastattelupohja.

Liite 2. Raportti Säkylän Pyhäjärven ammattikalastajien haastatteluista. 


\section{JOHDANTO}

Suomessa on runsaasti vesistöjä, joiden särkikala-, ahven- ja kuorekantoja ei kaupallisessa kalastuksessa hyödynnetä. Näiden kalojen raaka-ainearvo on ollut toistaiseksi niin alhainen, että niiden markkinahinta ei kata pyyntikustannuksia (mm. Käyhkö ym. 1997, Setälä ym. 2011). Eräiden järvien kalakantoja on kuitenkin pystytty hyödyntämään hyvinkin intensiivisesti erilaisten hoitokalastus- ja järvenkunnostushankkeiden puitteissa, kun kalastajalle on maksettu saalis- tai pyyntiponnistusperusteista hintatukea. Näissä hankkeista on kertynyt arvokasta tietoa, jonka perusteella kalavarojen tuottavuutta ja saaliskapasiteettia voidaan arvioida. Erillishankkeista kertyneet aineistot ovat kuitenkin olleet hajallaan eri toimijoilla, joten tietoja ei ole systemaattisesti analysoitu kokonaisuutena.

Viimeaikaisissa alueellisissa hankkeissa on kehitetty kalamassan käyttöä esimerkiksi elintarvikkeiden raaka-aineena tai vaikkapa vähäpäästöisenä energianlähteenä (mm. Deinhardt 2018, Huttunen 2018). Jotkut kehitetyistä tuotteista ovat olleet niin onnistuneita, että tuotannossa on törmätty yllättäen raaka-ainepulaan (esim. Satakunnan kalaelintarvikehankkeet). Ekologisesti kestävästi tuotettu matalan hiilijalanjäljen lähiruoka on nopeasti kasvava trendi elintarvikemarkkinoilla. Maailman väestönkasvu ja ilmastomuutoksen aiheuttaman ruuantuotanto-ongelmat lisäävät globaalisti eläinproteiinin kysyntää. Ravinnevarat, erityisesti fosfori, ehtyvät, mikä vaarantaa elintarviketuotannon perustaa. Toisaalta ravinteet kertyvät järviin siinä määrin, että niistä on huomattavaa haittaa monien ekosysteemipalvelujen tuotannolle. Kaikkien edellä kuvattujen trendien seurauksena sisävesikalan raakaainearvon ja markkinahinnan voi odottaa nousevan tasolle, jolla sen hyödyntäminen on kannattavaa ilman tukea, mikäli saalis yksikkötyökustannusta kohden on riittävän suuri - siis hyödynnettävä kanta on riittävän tiheä ja yksikkötyökustannukset (pyynti ja kuljetus) riittävän alhaiset. Ajantasainen tieto kalavarojen runsaudesta, tuottavuudesta ja alueellisesta jakaumasta luo edellytykset ennakoivalle, monipuoliselle ja kannattavalle kalavarojen hyödyntämiselle.

Kalavaroja, kalastusta ja saalista koskevaa tietoa on kertynyt paljon, mutta se on hajallaan. Erilaisissa hoitokalastushankkeissa kertyy jatkuvasti uutta tietoa. Uuden kalastuslain mukainen kaupallisten kalastajien saaliskirjanpitovelvollisuus tuo käyttöön uuden laajan tietovarannon, jota tulisi hyödyntää tehokkaasti kalastajien ja yhteiskunnallisen päätöksenteon tietotarpeisiin. Luonnonvarakeskus (2018) ja Suomen ympäristökeskus (Koljonen ym. 2019) ovat julkaisseet ohjeita kalastuksen (kaupallinen elintarvike- ja hoitokalastus, vapaa-ajankalastus), velvoitetarkkailujen ja ympäristövaikutusten arvioinnin yhteydessä kertyvän kalabiologisen tiedon kokoamis- ja käyttöohjeita. Tehostettavaa on ohjeiden toimeenpanossa, kertyvän tiedon hyödyntämisessä ja saatavuudessa. Kalastajien pyyntityön yhteydessä kertyy myös muuta hyödyllistä tietoa (esim. kalaparvien liikkeistä tai kalatiheydestä kaikuluotauksessa), jota ei tällä hetkellä systemaattisesti koota standardoiduksi yhteiseksi tietovarannoksi. 


\subsection{Hankkeen tavoitteet}

Verkostohankkeen päätavoitteita olivat:

1. Arvioida sisävesien heikosti hyödynnettyjen kalavarojen (särki- ja lahna-, ahven- ja kuorekannat) runsaus ja ekologisesti kestävä saalispotentiaali, jolla tarkoitetaan lajikohtaista kalatuotannon osaa, jota on mahdollista hyödyntää ekologisesti kestävästi.

2. Selvittää vajaasti hyödynnettyjen kalavarojen arviointityön tietotarpeet ja kehittää tieteellistä perustaa arvioinnin toteuttamiseen kustannustehokkaasti.

3. Käynnistää näiden kalavarojen tilaa koskevan tietojärjestelmän suunnittelu.

Näiden toimenpiteiden tavoitteena oli lisätä vajaasti hyödynnettyjen kalakantojen käytön tehokkuutta ja tuottavuutta, jotta hyödyntäminen olisi jatkossa taloudellisesti kannattavampaa sekä ekologisesti ja sosiaalisesti kestävää.

\subsection{Hankkeen yhteistyötahot ja keskeiset sidosryhmät}

Hanke toteutettiin Jyväskylän yliopiston bio- ja ympäristötieteiden laitoksen, Luonnonvarakeskuksen sekä Pyhäjärvi-instituutin yhteistyönä. Hankkeen vastuututkijana toimi FT Timo Ruokonen Jyväskylän yliopistosta.

Kalastajakumppaneina toimi kolme hoitokalastukseen erikoistunutta yrittäjää sekä kaksi kalastajaa, jotka kalastavat tai ovat aikeissa kalastaa särkikaloja elintarvikkeeksi ilman vesienhoidollisia tavoitteita.

Lisäksi Uudenmaan ympäristökeskuksessa toimineen hoitokalastusryhmän mittava saalisaineisto saatiin hankkeen käyttöön Varsinais-Suomen ELY-keskukselta. Myös ryhmän edustajat osallistuivat haastatteluun.

Lisäksi hankkeen aikana tehtiin aktiivista yhteistyötä muiden aihepiiriä käsittelevien hankkeiden toimijoiden kanssa. Tietoa ja tuloksia jaettiin puolin ja toisin mm. Järvi-Suomen kalatalousryhmän Vakava-verkostohankkeen, Kaakkois-Suomen ammattikorkeakoulun Nostetta särkikaloista -hankkeen, Luonnonvarakeskuksen Uusivu-hankkeen ja Kalastuksen innovaatio-ohjelmien hankkeiden kanssa, Kuusamon särkihankkeiden toimijoiden kanssa sekä Suomen ympäristökeskuksen Kiertokala-hankeen vetäjän kanssa.

Hankkeen ohjausryhmään kuuluivat hydrobiologi Antti Haapala (Etelä-Savon ELY-keskus/Kaakkois-Suomen ELY-keskus), kalastusbiologi Hannu Salo (PohjoisSavon ELY-keskus, Järvi-Suomen kalatalousyksikkö) ja toiminnanjohtaja Juha Piilola (Suomen sisävesiammattikalastajat ry). 


\section{AINEISTO JA MENETELMÄT}

Tuotanto- ja saalispotentiaaliarvioiden perustaksi kerättiin saatavilla oleva kokemusperäinen ja julkaistu tieto vajaasti hyödynnettyjen kalakantojen runsaudesta, saaliista ja vasteesta kalastukseen. Tuotantopotentiaalilla tarkoitetaan tässä suurinta mahdollista jatkuvaa kalatuotantoa. Kerätyn aineiston pohjalta laadittiin lajikohtaiset (särki, ahven) biomassa-tuotantomallit erilaisille järvityypeille järven koon, vedenlaatumuuttujien sekä ilmastovyöhykkeen/maantieteellisen sijainnin perusteella. Yleisten tuotantomallien laatiminen muille jo tällä hetkellä tai tulevaisuudessa hyödynnettäville lajeille (mm. lahna, kuore, sulkava) ei kuitenkaan ollut mahdollista vähäisen tausta-aineiston vuoksi.

\subsection{Aineistolähteet}

Järvien vajaasti hyödynnettyjen kalalajien saalispotentiaalin arvioimistyön taustaksi kerättiin saatavilla oleva tieto hoitokalastushankkeista hoitokalastuksia toteuttaneilta kalastajilta/yrityksiltä, hankehenkilöiltä, kalatalouskeskuksilta ja ELY-keskuksilta. Näiden lisäksi tietoja haettiin internetistä, tutkimusjulkaisuista ja hankeraporteista. Aiheeseen liittyvää tiedekirjallisuutta haettiin Google Scholar - ja ISI - Web of Knowledge -tietokannoista. Lisäksi hoitokalastuskohteista kerättiin tietoa vesimuodostuman pinta-alasta, syvyydestä, keskisyvyydestä ja vedenlaatumuuttujista Suomen ympäristökeskuksen ylläpitämästä Hertta-tietokannasta.

Hoitokalastuksia toteuttaneilta ja vajaasti hyödynnettyjä lajeja elintarvikkeeksi kalastaneilta kalastajilta hankittiin saaliskirjanpitotietoja korvausta vastaan. Tietojen määrä ja sisältö vaihtelivat toimijakohtaisesti yksittäisistä järvistä kymmeniin kohteisiin. Lisäksi Varsinais-Suomen ELY-keskukselta saatiin käyttöön Uudenmaan ympäristökeskuksen hoitokalastusryhmän noin 50 järveltä keräämä aineisto, joka sisältää runsaasti järvikohtaista saalis- ja lajijakaumatietoa useiden vuosien ajalta.

Kaikki hoitokalastussaaliista kerätty järvi- ja aluekohtainen tieto on koottu yhteen Excel-tiedostoon. Tällä hetkellä aineisto on saatavilla hankkeessa toimineilta Jyväskylän yliopiston tutkijoilta. Aineisto voidaan sijoittaa paremmin saataville esimerkiksi osaksi Suomen ympäristökeskuksen vesistökunnostusverkoston sivustoja, mutta neuvottelut käytännön järjestelyistä ovat tätä kirjoitettaessa kesken.

Luonnonvarakeskus toimitti hankkeen käyttöön EU:n vesipuitedirektiivin toimeenpanoon liittyvän järvien ekologisen tilan arvioitiin käytettävän Nordicverkkokoekalastusaineiston. Tämä koko maan kattava yli 500 vesimuodostuman aineisto sisältää mm. eri kalalajien yksikkösaaliit eri tyyppisistä vesistöistä. Aineistoa hyödynnettiin tausta-aineistona saalispotentiaalien alueellisten erojen selvittämisessä.

Nykyisten ja viime vuosien kohdelajien (särki, ahven, lahna, kuore) saalisarviot perustuivat Luonnonvarakeskuksen sisävesien kaupallisten ja vapaa-ajan kalastajien saalistilastotietokantoihin (SVT: Luonnonvarakeskus). 


\subsection{Saalispotentiaaliarviot}

\subsubsection{Järvien luokittelu tuotantopotentiaalin mukaisesti}

Järvien kalatuotanto- ja saalispotentiaaliin vaikuttavat $\mathrm{mm}$. maantieteellinen sijainti, morfometriset piirteet ja veden laatu. Tästä syystä järvet jaettiin saalipotentiaalilaskelmia varten kolmeen tyyppiin. Jaottelussa käytettiin pohjana vesimuodostumien jakoa eri vesistötyyppeihin (Pilke 2012). Pintavesien ekologisen tilan määrittämistä ja seurantaa varten tehty järvien tyypittely 15 eri tyyppiin osoittautui tähän käyttöön liian yksityiskohtaiseksi, joten järvityyppejä yhdistettiin siten, että saatiin muodostettua kolme päätyyppiä:

isot karut/karuhkot järvet (pinta-ala $>4000$ ha)

keskikokoiset ja pienet karut/karuhkot järvet (pinta-ala $\leq 4000$ ha)

keskikokoiset ja pienet rehevät järvet (pinta-ala $\leq 4000$ ha),

joiden kalantuotantopotentiaalin arvioitiin tutkimuskirjallisuuden perusteella eroavan toisistaan. Maantieteellisesti Suomi jaettiin kolmeen maantieteelliseen alueeseen:

Etelä- ja "Keski-Suomi": Etelä-Pohjanmaa, Keski-Suomi, Pohjois-Savo, PohjoisKarjala ja niiden eteläpuoliset maakunnat)

Pohjois-Pohjanmaa ja Kainuu

Lappi

Saalispotentiaalilaskelmia varten määritettiin järvien yhteispinta-alat vesistötyypeittäin eri ELY-keskusten alueilla. Pinta-alalaskelmissa ovat mukana kaikki yli 100 ha järvet ja osa pienemmistä. Särjen ja ahvenen levinneisyysalueet (http://kalahavainnot.fi/) eivät kata koko Suomea, joten niiden esiintymisalueiden ulkopuolella olevat järvet rajattiin pois laskemista. Lapin särkijärvien pinta-alat määritettiin QGIS-paikkatieto-ohjelmistolla Luonnonvarakeskuksen kala-atlaksen (http://kalahavainnot.fi/) lajihavaintotietojen ja Suomen ympäristökeskuksen vesimuodostumatietojen perusteella. Ahven ei myöskään esiinny Lapin korkealla sijaitsevissa järvissä, joten männyn puurajan yläpuolella olevat järvet (järvityyppi pohjoisen Lapin järvet, PoLa) rajattiin pois saalispotentiaalilaskelmista. Järvien luokittelu- ja tyypittelyaineiston toimitti Jukka Aroviita Suomen ympäristökeskukselta. Paikkatietoaineisto (VHS vesimuodostumat) ladattiin Suomen ympäristökeskuksen ylläpitämästä LAPIO-palvelusta. Aineisto kattaa kaikkiaan noin 85 \% järvien kokonaispinta-alasta. 


\subsubsection{Biomassa-, tuotanto- ja saalispotentiaaliarviot, kestävyys}

Saalispotentiaali määritettiin soveltaen ns. ylijäämätuotantomallia (esim. Graham 1935). Jotta populaation biomassa pysyy vakiotasolla, saaliiksi pitää vuosittain ottaa populaation ylijäämätuotanto eli se määrä (massa), jonka populaation koko kasvaisi vuodessa, jos sitä ei kalastettaisi. Ylijäämätuotanto riippuu populaation biomassasta seuraavasti:

Jos populaation biomassa on ympäristön kantokyvyn mukaisella maksimitasolla, niin ylijäämätuotanto on nolla. Ilman kalastusta populaation biomassa siis ennen pitkää kasvaa maksimitasolle, jolloin populaation koko pysyy vakiona lukuun ottamatta vuosien välistä ympäristöolojen satunnaisvaihteluiden aiheuttamaan heilahtelua (dynaaminen tasapaino). Ympäristön kantokyky riippuu yleensä ravintovarojen tuotannosta. Karussa järvessä kantokyky on siis alempi kuin rehevässä ja siksi maksimibiomassa pienempi. Myös järven muotosuhteet vaikuttavat biomassaan. Jos järvi on laaja ja syvä, niin litoraalissa (rantavyöhyke) viihtyvien kalalajien (mm. särki, ahven) keskimääräinen hehtaaribiomassa on pienempi kuin matalissa ja pienissä järvissä, jotka voivat olla käytännössä kokonaan tuottavaa litoraalia.

Kun populaatioon kohdistuu vuodesta toiseen kalastus, jonka pyyntiponnistus ja siten myös kalastuskuolevuus on vakio, populaation biomassa hakeutuu kantokykyä alempaan dynaamiseen tasapainoon. Mitä suurempi tämä kalastuskuolevuus on, sitä pienempi on tasapainobiomassa. Mitä vähemmän kalaa vesialueella on, sitä enemmän voimavaroja (resursseja) kaloilla on käytettävissä yksilöä tai esim. massayksikköä kohden. Biomassan pienentyessä yksilöiden kasvunopeus ja lisääntymismenestys kasvavat ja luonnollinen kuolevuus (muu kuin kalastuskuolevuus) saattaa pienentyä. Nämä prosessit aiheuttavat yksilökohtaisen tuotannon kasvua biomassan pienentyessä. Yksilöä (kpl) ja biomassayksikköä (esim. kg) kohden siis syntyy populaation pienentyessä yhä enemmän ylijäämätuotantoa, joka voidaan korjata talteen. Koko populaation ylijäämäätuotanto eli tasapainosaalis on silloin

tasapainosaalis $=$ biomassa $\times$ biomassayksikön ylijäämätuotanto

Koska kalastuskuolevuuden kasvaessa biomassa pienenee ja biomassayksikön ylijäämätuotanto kasvaa (yleensä asymptoottisesti), ylijäämätuotanto ja tasapainosaalis ovat suurimmillaan, kun kalastuskuolevuus on sellainen, että tasapainokalabiomassa on keskinkertainen - käytännössä yleensä noin puolet maksimibiomassasta. Tämä suurin tasapainosaalis on saalispotentiaali (engl. MSY = maximum sustainable yield, suurin mahdollinen jatkuvasti saatavissa oleva saalis, myös saaliskapasiteetti).

Kun kalabiomassa on nolla, myös ylijäämätuotanto eli tasapainosaalis on nolla. 
Särjen ja ahvenen saalispotentiaali määritettiin järvityypeittäin ja alueittain (luku 2.1.1.) seuraavasti

$$
\operatorname{MSY}_{1, j, a}=\operatorname{Bmax}_{1, j, a} \times p_{1, j, a} \times F_{l, j, a}
$$

jossa $\mathrm{l}=$ laji, $\mathrm{j}=$ järvityyppi, $\mathrm{a}=$ alue, Bmax = kantokyvyn mukainen maksimibiomassa $(\mathrm{kg} / \mathrm{ha}), \mathrm{p}=$ osuus (\%) maksimibiomassasta, joka tuottaa suurimman tasapainosaaliin, $\mathrm{F}=$ vakio kalastuskuolevuus (n. $\mathrm{r} / 2$, jossa $\mathrm{r}=$ populaation kasvunopeus, intrinsic rate of increase, intrinsic growth rate), jolla tavoiteltu biomassa $\left(\operatorname{Bmax}_{\mathrm{l}, \mathrm{j}, \mathrm{a}} \times \mathrm{p}_{\mathrm{l}, \mathrm{j}, \mathrm{a}}\right)$ saavutetaan. Esim. yksinkertaisimman Grahamin mallin teoreettinen tausta ja matemaattinen esitys (Anonyymi 2019a).

Yhtälön parametrien arvot oli alun perin tarkoitus määrittää julkaistujen särkija ahvenpopulaatioiden tuotantobiologisten parametriarvojen ja hyvin dokumentoitujen hoitokalastuskokeilujen analysoinnista saatavien tulosten avulla. Aineistojen tarkastelussa ilmeni, että särjen ja ahvenen tuotantobiologisia tutkimuksia on julkaistu jonkin verran (mm. Tuunainen 1970, Rask \& Arvola 1985, Rask \& Ruuhijärvi 1990, Peltonen \& Horppila 1992, Sarvala ym. 1992, Horppila \& Peltonen 1994, Karjalainen ym. 1999, Olin ym. 2002, Lappalainen ym. 2008, Horppila ym. 2010, Rask ym. 2014, Malinen ym. 2017, Olin ym. 2017), mutta niiden kohdejärvet eivät edusta hyvin perusjoukkoa, Suomen järviä. Hyvin dokumentoituja hoitokalastuskokeiluaineistoja oli käytettävissä melko runsaasti, kymmeniä, mutta vain hyvin harvoissa tapauksissa tilastoissa ilmeni niin selvää yksikkösaaliin laskua, että kalabiomassan voitiin tulkita pienentyneen kalastuskuolevuuden kasvun myötä. Aivan ilmeisesti siis hoitokalastussaalis oli kalatuotantoon verrattuna pieni osa ja/tai pyynnit oli toteutettu esimerkiksi niin, että eri vuosina kalastettiin järven eri osaalueilta, jolloin yksikkösaaliissa ei ilmennyt jonkun tietyn alueen vaste kalastukseen.

Yhtälön parametrien arvot päädyttiin em. syistä määrittämään asiantuntijaarviona eikä analyyttisesti. Asiantuntija-arviot muodostettiin käyttämällä kaikkea käytettävissä olevaa tietoa: tieteelliset julkaisut, hankeraportit, dokumentoidut kokeilut sekä kalastajien ja hankkeissa mukana olleiden kokemusperäiset arviot, jotka hankittiin haastatteluin ja työpajoissa.

Varsinaisen saalispotentiaaliarvion lisäksi on tärkeätä muodostaa käsitys siitä, miten tarkka ja täsmällinen varsinainen todennäköisin saalispotentiaaliarvio on. Tämän vuoksi saalispotentiaalia (MSY, kaava yllä) laskettaessa yhden parametriarvon sijasta käytettiin parametrin todennäköisyysjakaumaan perustuvia arvioita. Tätä varten arvioitiin, mikä on em. kaavan kunkin parametrin todennäköisin arvo ja pienin ja suurin mahdollisena pidetty arvo. Näistä muodostettiin kolmiotodennäköisyysjakauma (triangle distribution). Laskennassa käytetyt muuttujien $\operatorname{Bmax}_{1, j, a}, p_{l, j, a}$ ja $F_{l, j, a}$ arvot poimittiin satunnaisesti näistä jakaumista ja lasketun tulosmuuttujan MSY $_{1, j, a}$ arvo tallennettiin. Tätä toistettiin yleensä 5000 kertaa @RISK-ohjelmiston (Palisade) avulla. Tuloksista laskettiin keskiarvo (paras arvio) sekä todennäköisyysjakauma. Esim. tulosten 50 \% todennäköisyysväli ilmentää sitä, että tietojen epävarmuudet huomioiden todellinen saalispotentiaali on annetulla välillä noin $50 \%$ todennäköisyydellä.

Kestävällä saalispotentiaalilla tarkoitetaan tässä raportissa suurinta saalista, joka pyynnin kohteena olevasta kalapopulaatiosta voidaan keskimäärin vuodessa 
ottaa populaation jatkuvasti pienenemättä. Saalis voi kuitenkin vaihdella vuosien välillä esim. tuotannon satunnaisvaihtelun vuoksi. Saalis voidaan myös pyytää intervallipyyntinä eli pulssipyyntinä, esim. erittäin voimakas pyynti muutaman vuoden ajan ja sen jälkeen joidenkin vuosien kalastamaton toipumisjakso pyynnin aiheuttamasta populaation pienenemisestä.

Kalastuslaki edellyttää, että pyynnin pitää olla ekologisesti/biologisesti kestävää. Ekologisesti/biologisesti kestävällä saalispotentiaalilla tarkoitetaan tässä suurinta saalista, joka pyynnin kohteena olevasta kalapopulaatiosta voidaan keskimäärin vuodessa ottaa 1) populaation jatkuvasti pienenemättä ja perimältään merkittävästi muuttumatta. Pyynnin kohdepopulaation kannalta suuren saaliin saaminen jatkuvasti edellyttää siis lähtökohtaisesti populaation pitämistä elinkykyisenä. Pyynnin on kuitenkin oltava populaation keskeisten periytyvien elinkiertopiirteiden (esim. kasvunopeus, sukukypsyyden saavuttamisikä ja -koko) osalta mahdollisimman valikoimatonta, jotta merkittävää geneettistä muutosta näissä ominaisuuksissa ei tapahdu.

Toinen keskeinen ekologisen/biologisen kestävyyden kriteeri on, että 2) kohdepopulaation pyynti ei aiheuta merkittäviä muutoksia muiden kalapopulaatioiden elinkyvylle vesistössä - siis sukupuuton uhkaa tai merkittäviä geneettisiä muutoksia - eikä pysyviä muutoksia ekosysteemin toimintakyvyssä tai monimuotoisuudessa. Pyynti pitää siis toteuttaa niin, että sivusaalispopulaatioiden kalastuskuolevuus ei aiheuta näille lajeille sukupuuton uhkaa tai geneettisiä muutoksia.

Ekologinen kestävyys on yleensä taloudellisen ja sosiaalisen kestävyyden edellytys. Joissakin tapauksissa tietenkin ns. hoitokalastuksessa voidaan tietoisesti pyrkiä haitalliseksi koetun kalakannan hävittämiseen, suorastaan sukupuuton aiheuttamiseen (erityisesti haitalliset vieraslajit), jolloin sosiaalinen ja taloudellinen kestävyys toteutuu ekosysteemin muiden ekosysteemipalvelujen parantuessa. Särki ja ahven ovat kuitenkin yleensä vesialueella luonnostaan esiintyviä kalalajeja, joten niiden sukupuuton tavoittelu on periaatteessa kalastuslain vastaista.

Tämän hankkeen yhteydessä kootun tiedon perusteella ei voida arvioida sitä, miten kalastus olisi käytännössä järjestettävissä kaikkien kestävyyskriteerien mukaisesti yksittäisessä järvessä. Esitetyt saalispotentiaalislaskelmat kuvaavatkin teoreettista maksimaalista saalista, mutta on todennäköistä, että järvikohtaiset sekä biologiseen/ekologiseen ja sosiaaliseen kestävyyteen liittyvät seikat rajoittavat mahdollisuutta saavuttaa potentiaali käytännössä.

Kestävyyden kriteereistä ja tunnusmerkeistä laajemmin esim. Salmisen \& Böhlingin (2019) toimittamassa oppaassa.

\subsection{Kalastajakumppanien haastattelut}

Numeeristen aineistojen keräämisen lisäksi haastateltiin hankkeen viisi kalastajakumppania, jotta saataisiin käytännön toimijoiden kentällä kertynyt tieto ja näkemykset saalispotentiaaliarvioiden pohjaksi sekä tietoa toiminnan yleisistä reunaehdoista. Haastattelut tehtiin ennakkoon jäsennellyn kysymyspohjan avulla (Liite 1). Haastattelut tallennettiin äänitallentimella ja litteroitiin kirjalliseen muotoon 
jälkikäteen. Haastattelujen kesto ja käsitellyt aiheet vaihtelivat toimijakohtaisesti riippuen haastateltavan tahon toiminnan laajuudesta ja kokemuksesta.

Kalastajakumppanien haastattelujen lisäksi Pyhäjärvi-instituutti haastatteli Säkylän Pyhäjärven kalastajia saalispotentiaalista ja tulevaisuuden näkymistä osana laajempaa kalastajien olosuhteita selvittänyttä kyselyä. Pyhäjärven haastattelun tulokset julkaistiin erillisenä raporttina (Liite 2). 


\section{TULOKSET JA TULOSTEN TARKASTELU}

\subsection{Kaupallisten ja vapaa-ajan kalastajien saaliit}

Sisävesien kaupallisen kalastuksen särkisaalis on vaihdellut jaksolla 2000-2017 puolesta miljoonasta miljoonaan kiloon (Kuva 1). Suurimmat saaliit on saatu tarkastelujakson alussa ja loppuvuosina. Alkuvuosien saalis on todennäköisesti pääosin hoitokalastussaalista, mutta viime vuosina elintarvikkeeksi kalastettavan särjen määrä lienee kasvanut. Tilastoista ei voi eritellä saalista käyttötarkoituksen mukaan (Luonnonvarakeskus 2019).

Vapaa-ajan kalastuksen särkisaalis on yli nelinkertainen verrattuna kaupallisen kalastuksen saaliiseen ja pysynyt tarkastelujakson aikana jokseenkin samalla tasolla vuodesta toiseen (Kuva 2).

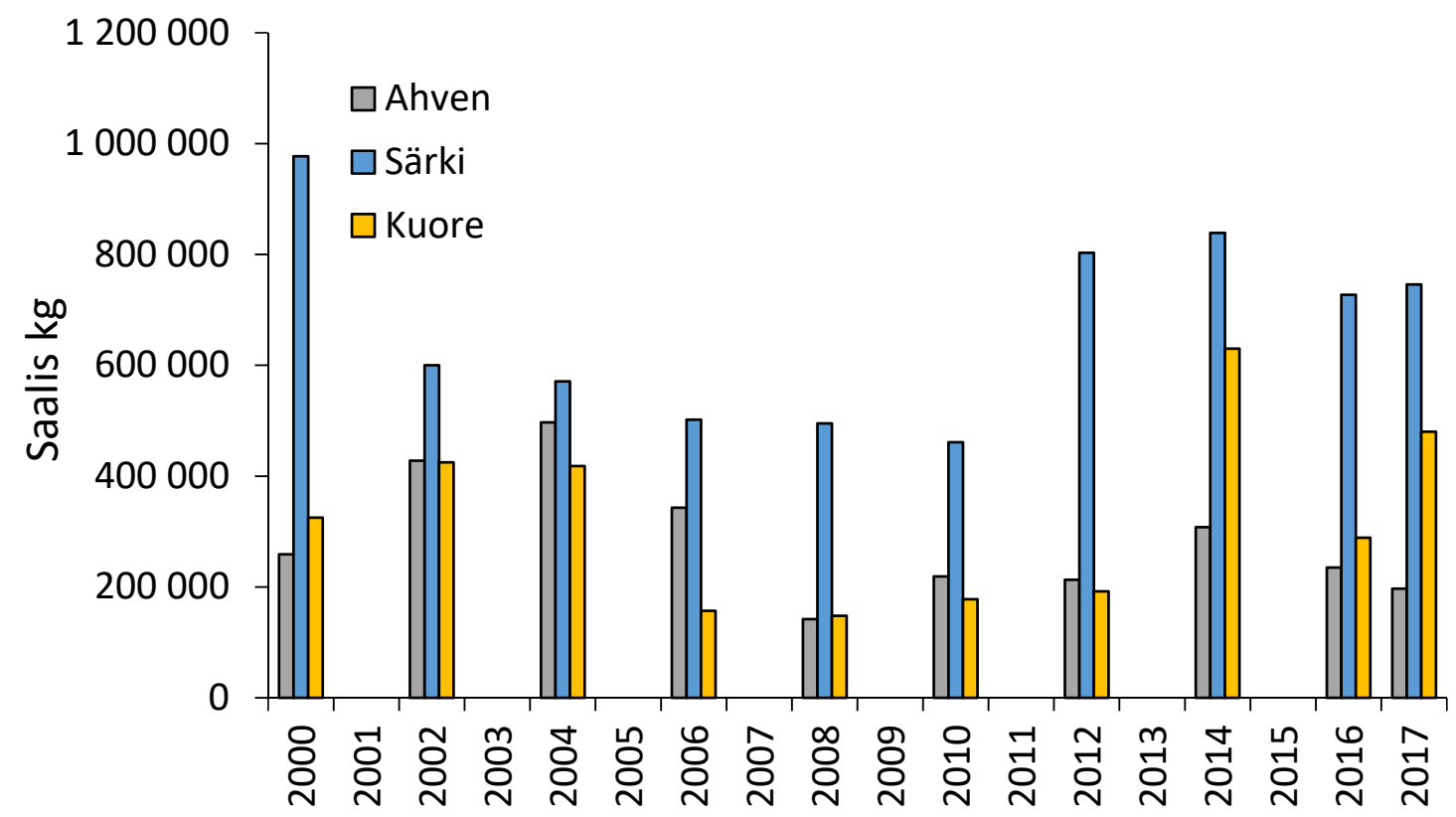

KUVA 1 Kaupallisen kalastuksen ahven-, särki- ja kuoresaalis sisävesillä vuosina 2000-2017 (Luonnonvarakeskus 2019).

Sisävesien kaupallisen kalastuksen ahvensaalis vaihdellut tarkastelujaksolla noin 100000 kg:sta 400000 kg:n (Kuva 1). Vapaa-ajan kalastuksen ahvensaalis on noin 20kertainen verrattuna kaupallisen kalastuksen saaliiseen (Kuva 2). 


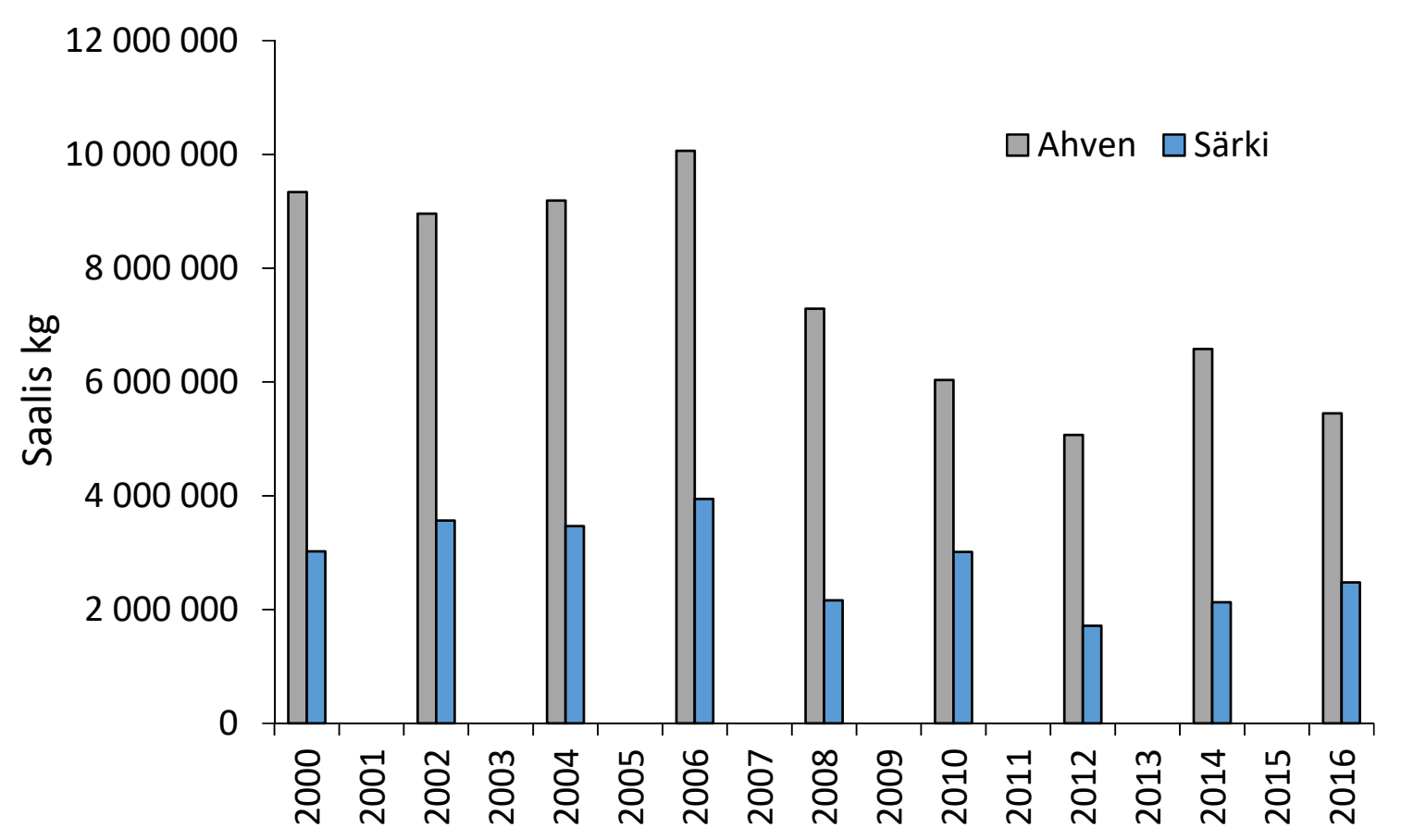

KUVA 2 Vapaa-ajan kalastuksen ahven- ja särkisaalis sisävesillä vuosina 2000-2016 (Luonnonvarakeskus 2019).

Sisävesien kaupallisen kalastuksen vuotuinen kuoresaalis on vaihdellut 150000 kg ja 630000 kg:n välillä.

\subsection{Hoitokalastuskohteet, saaliit ja eri lajien saalisosuudet}

Hankkeessa saatiin kerättyä pyynti- ja saalistietoja yhteensä 148 vesimuodostumasta eri puolilta Suomea (Kuvat 3-5). Tiedon tarkkuus vaihteli kokonaissaalistiedosta yksityiskohtaiseen tietoon kalasaaliin rakenteesta ja pyyntiponnistuksesta pyydyksittäin. Iso osa aineistosta oli kuitenkin tallennettu karkealla tasolla (esim. kokonaissaalis vuosittain). Kerätty aineisto ei kata kaikkia Suomessa tehtyjä hoitokalastushankkeita. Erityisesti pienempiä osakaskuntien omana työnä tekemiä hoitokalastuksia puuttuu kootusta aineistosta.

Hoitokalastuskohteiden määrä vuositasolla on pysynyt 1990-luvun lopun jälkeen melko tasaisena. Kohteita on ollut keskimäärin noin 40 vuodessa (Kuva 3). Hoitokalastuksia on tehty vuosien varrella kaikkien nykyisten vesienhoidosta vastaavien ELY-keskusten alueilla (Kuva 3 \& 5). Kohteiden sijoittumisessa on kuitenkin selvästi havaittavissa keskittymiä: selvästi eniten hoitokalastuskohteita on ollut Uudellamaalla, Päijät-Hämeessä, Etelä-Savossa ja Kuusamon seudulla (Kuva 3 \& 5). Kuusamon alueen kohteissa kalastus on tavanomaisesta hoitokalastuksesta poiketen enenevissä määrin särjen kalastusta elintarvikkeeksi. Lapissa vajaasti hyödynnettyjä lajeja on pyydetty toistaiseksi vielä vähän, lukuun ottamatta Lokan 
tekoallasta, josta kalastettiin 2010-luvun taitteessa kolmen vuoden aikana yli 250000 kiloa pääasiassa särkikaloja.

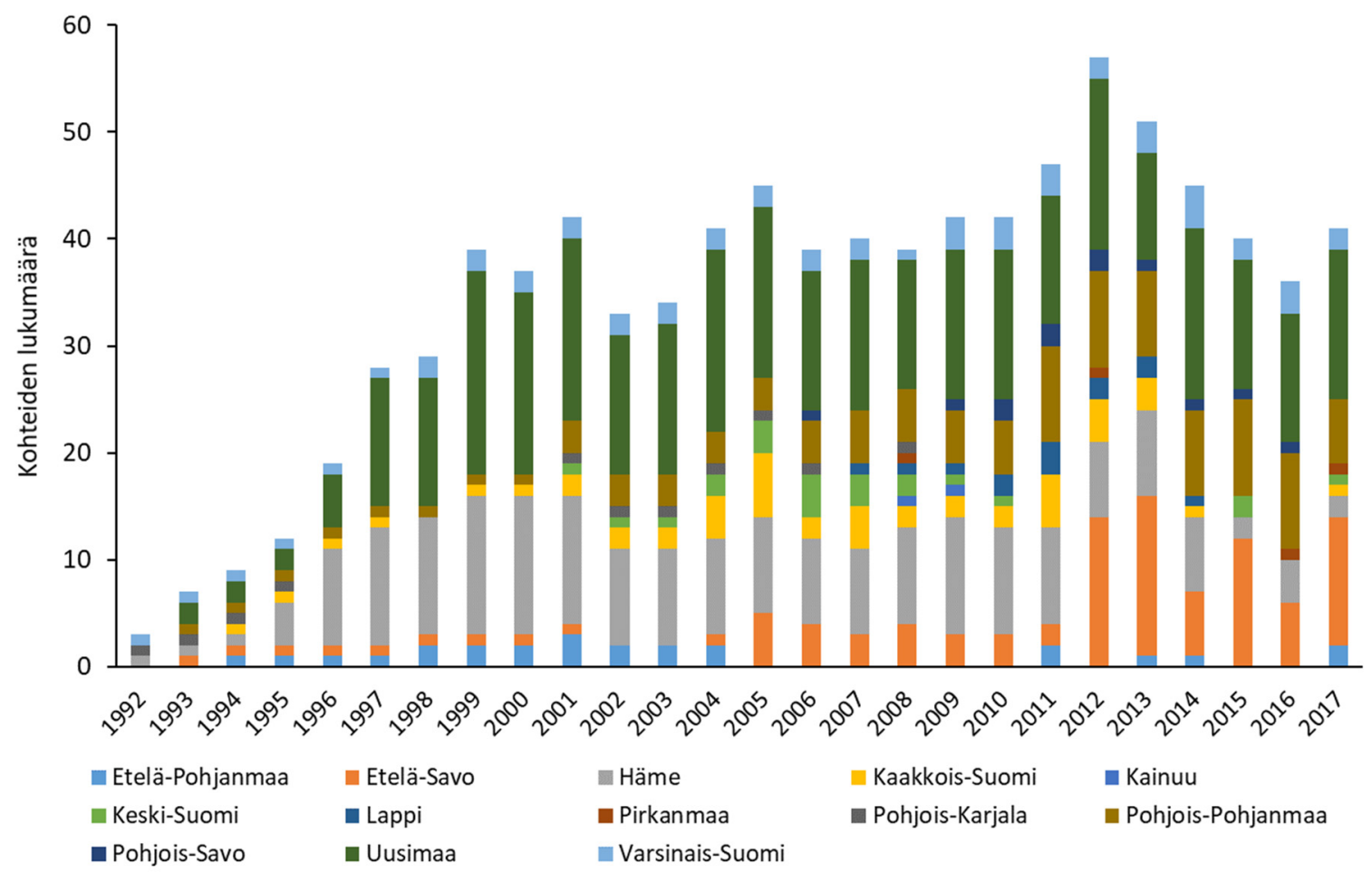

KUVA 3 Hoitokalastuskohteiden määrä vuosina 1992-2017 ELY-keskuksittain.

Hoitokalastusten vuosittaiset kokonaissaaliit ovat vaihdelleet tarkasteltavalla ajanjaksolla vuosien välillä huomattavasti (Kuva 4). Eniten saalista saatiin 2000-luvun alkupuolella, noin 1,5 miljoonaa kg/vuosi. 2000-luvun ensimmäisen vuosikymmenen toisella puoliskolla saalis notkahti 0,5 miljoonaan $\mathrm{kg} /$ vuosi, mutta nousi noin 1,1 miljoonan kg keskimääräiseen saaliiseen 2010-luvulla (Kuva 4). 


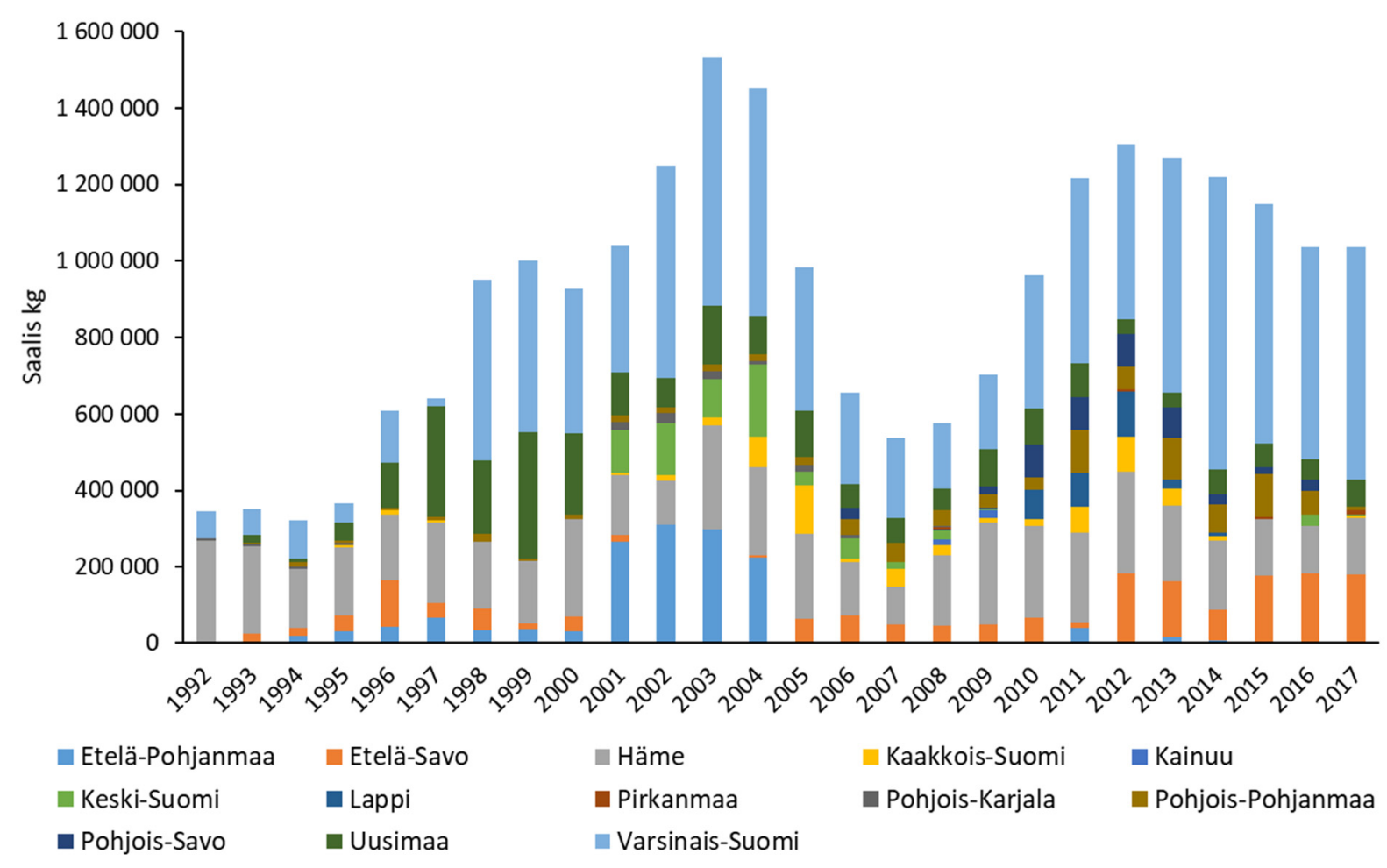

KUVA 4 Hoitokalastuskohteiden kokonaissaalis vuosina 1992-2017 ELY-keskuksittain.

1990-luvulla alkaneet isot hoitokalastushankkeet sijoittuivat pääasiassa Hämeeseen, Varsinais-Suomeen ja Uudellemaalle (Kuva 4 \& 5). Mm. Vesijärven, Hiidenveden, Tuusulanjärven, Köyliönjärven ja Säkylän Pyhäjärven hoitokalastushankkeissa kalastettiin vuosittain yhteensä satoja tuhansia kilogrammoja kalaa. Lisäksi isompia hoitokalastushankkeita toteutettiin 2000-luvulla Keski-Suomessa (Jyväsjärvi, Päijänne) ja Etelä-Pohjanmaalla (Lappajärvi), joiden myötä valtakunnallinen kokonaissaalis nousi ennätyslukemiin (Kuva 4).

Eniten saalista 2010-luvulla on saatu Varsinais-Suomen, Hämeen ja Etelä-Savon alueilta (Kuva 4). Varsinais-Suomen ELY-keskuksen alueella kohteiden vuosittainen määrä on ollut vähäinen, mutta Säkylän Pyhäjärven tehokas kalastus nosti alueen kokonaissaaliin korkeaksi aiempien vuosien tapaan. Etelä-Savossa hoitokalastuskohteiden määrä on kasvanut 2010-luvun loppua kohti ja saalismäärät kasvaneet keskimäärin 150000 kg:n vuosisaaliisiin. Uudellamaalla on viime vuosina kalastettu Tuusulanjärven lisäksi pääasiassa pienemmillä kohteilla. Alueen kokonaissaalis on ollut keskimäärin noin $65000 \mathrm{~kg}$ (Kuva 4). Joillakin alueilla (KeskiSuomi, Pirkanmaa, Etelä-Pohjanmaa, Pohjois-Karjala) hoitokalastustoiminta on viime vuosina ollut vähäistä sekä kohteiden lukumäärän kuin saaliin osalta (Kuvat 3 \& 4). 


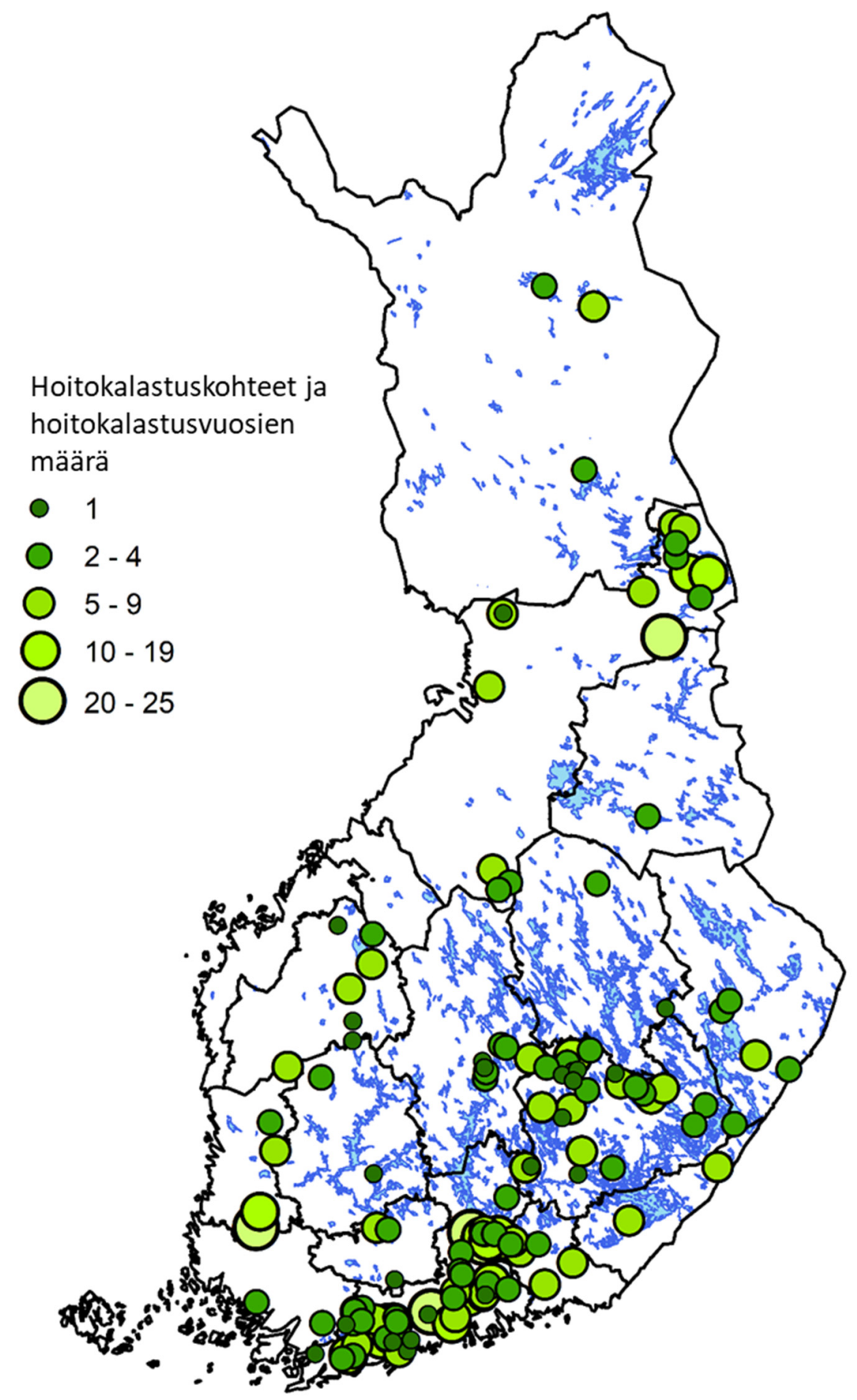

KUVA 5 Hoitokalastuskohteet Suomessa vuosina 1992-2017. Merkin koko ilmaisee, kuinka monena vuonna hoitokalastuksia on tehty. Kartta-aineisto: SYKE, ELY-keskukset.

Hoitokalastuksia on toteutettu eniten keskikokoisissa 100-1000 ha järvissä (Kuva 6 A). Hoitokalastussaaliit vesihehtaaria kohden ovat olleet keskimäärin korkeimpia pienissä (10-100 ha) järvissä (Kuva 6 B). Suurimmat vuosittaiset kokonaissaaliit on saatu suuremmista, yli 1000 hehtaarin järvistä (Kuva 6 C). Suurten järvien saaliit ovat kuitenkin vaihdelleet erittäin paljon kohteesta ja toiminnan laajuudesta riippuen (Kuva 6 C). 


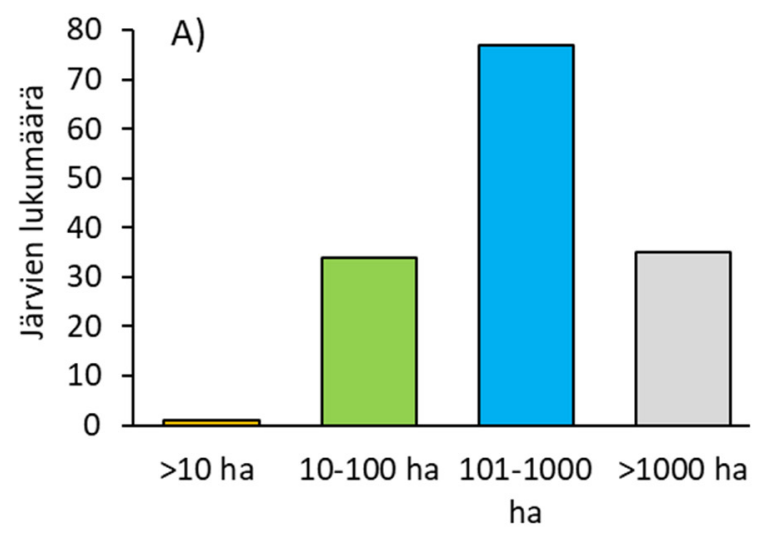

Järven kokoluokka

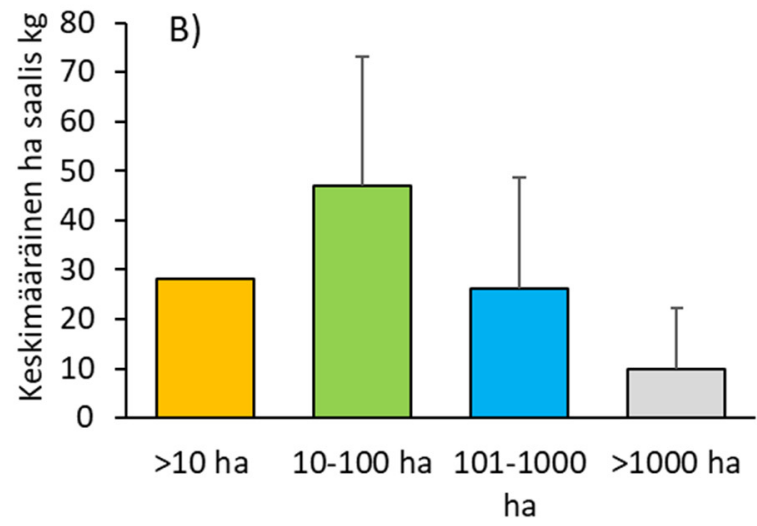

Järven kokoluokka

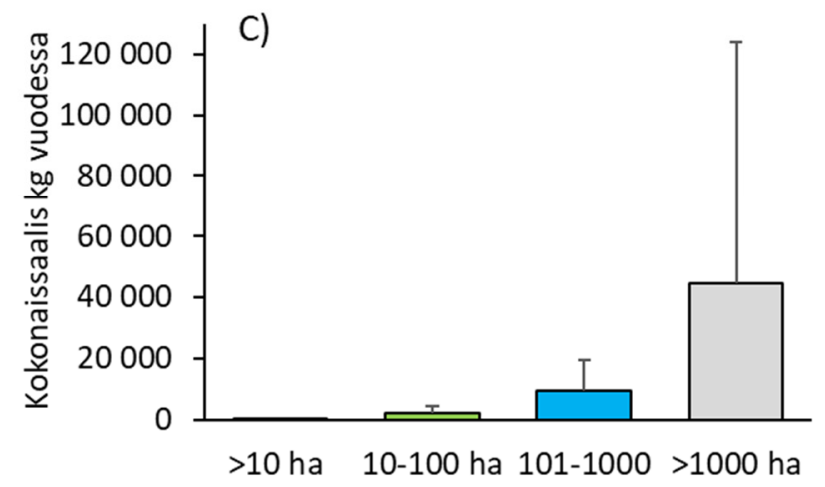

ha

Järven kokoluokka

KUVA 6 Hoitokalastettujen järvien A) jakaantuminen eri kokoluokkiin, B) keskimääräinen hehtaarisaalis vuodessa $(\mathrm{kg}$, jana = keskihajonta) ja $\mathrm{C})$ keskimääräinen kokonaissaalis $(\mathrm{kg}$, jana = keskihajonta) vuodessa kokoluokittain.

Hoitokalastettujen kohteiden keskimääräinen hehtaarisaalis oli noin $34 \mathrm{~kg}$ vuodessa (Taulukko 1). Hehtaarisaaliissa oli havaittavissa alueellista vaihtelua, mutta osalla alueista järvien ja havaintovuosien vähäinen määrä heikentää tulosten luotettavuutta ja yleistettävyyttä (Taulukko 1). Lisäksi pyyntiponnistuksessa ja kalastuksen tehossa on ollut järvien ja vuosien välillä paljon vaihtelua, joten hehtaarisaalisarviot ovat vain suuntaa-antavia esimerkiksi alueita ja paikkoja vertailtaessa. Hoitokalastushankkeissa on tyypillistä, että alun "tehovaiheessa" hehtaarisaaliit ovat pitkän aikavälin keskiarvosaaliita korkeampia. Toisaalta suurissa järvissä hoitokalastus voi olla keskittynyt vain pieneen osaan järveä, joten järven kokonaishehtaarisaalis voi olla pieni. 
TAULUKKO 1 Hoitokalastuskohteiden keskimääräinen hehtaarisaalis ja keskihajonta (ha-saalis \pm $\mathrm{kh})$, laskennassa käytettyjen järvikohtaisten havaintovuosien mediaani (Md) ja kohteiden määrä ELY-keskuksittain.

ELY-keskus ha-saalis keskimäärin $( \pm$ kh) Havaintovuosia (Md)

Kohteiden määrä

\begin{tabular}{llrr} 
Etelä-Pohjanmaa & $35(38)$ & 2 & 7 \\
Etelä-Savo & $19(19)$ & 2 & 28 \\
Häme & $18(20)$ & 15 & 16 \\
Kaakkois-Suomi & $17(12)$ & 6 & 9 \\
Kainuu & $97(-)$ & 2 & 1 \\
Keski-Suomi & $44(33)$ & 4 & 7 \\
Lappi & $11(18)$ & 4 & 3 \\
Pirkanmaa & $32(40)$ & 2 & 2 \\
Pohjois-Karjala & $56(48)$ & 4 & 3 \\
Pohjois-Pohjanmaa & $17(21)$ & 5 & 15 \\
Pohjois-Savo & $30(18)$ & 6 & 2 \\
Uusimaa & $33(23)$ & 4 & 49 \\
Varsinais-Suomi & $30(17)$ & 7 & 6 \\
\hline \hline
\end{tabular}

Hoitokalastussaaliiden lajijakauma on tärkeä tieto erityisesti kalan elintarvikekäytön lisäämisen kannalta, jotta jalostukseen saadaan riittävän suuria määriä haluttuja lajeja. Kerätyn hoitokalastusaineiston perusteella (51 järvestä tiedossa saalisjakauma lajeittain) saaliista oli keskimäärin eniten särkeä (43 \%) ja lahnaa (30 \%) (Kuva 7).

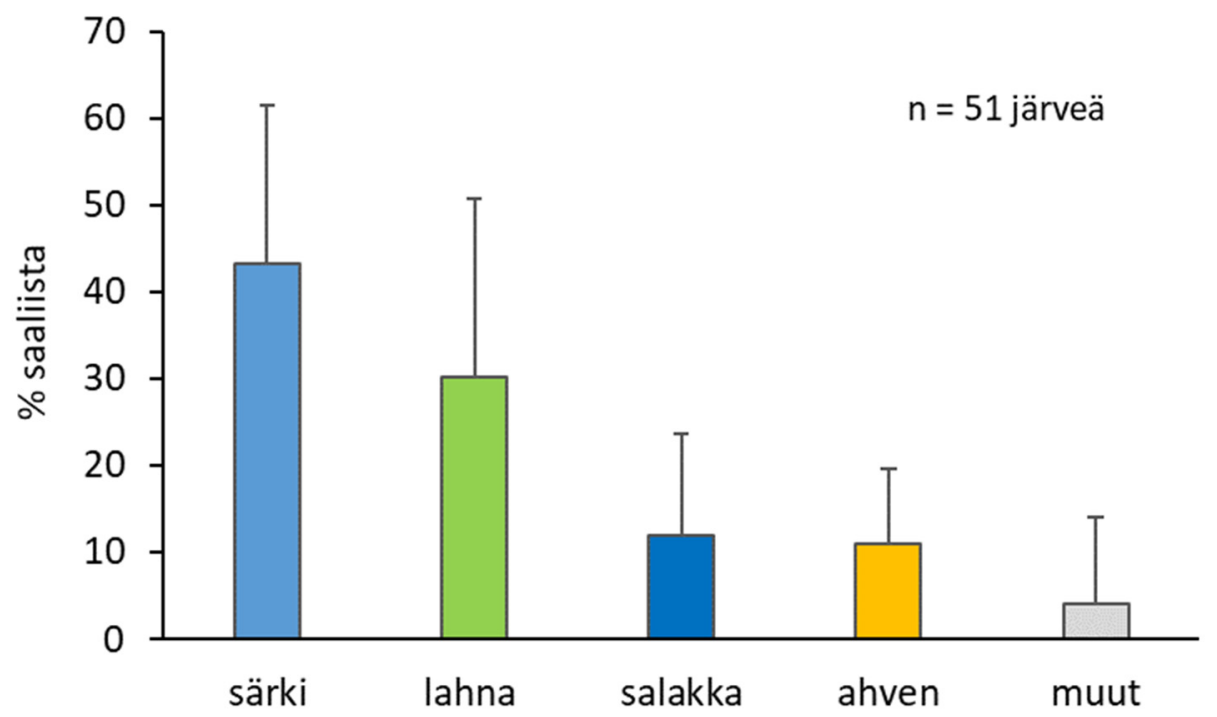

KUVA 7 Hoitokalastussaaliiden lajijakauma (keskiarvo, jana = keskihajonta).

Saaliin lajisuhteissa oli kuitenkin runsaasti vaihtelua järvien välillä. Esimerkiksi särjen osuus saalista vaihteli välillä $10-86 \%$. Lahnalla saalisosuuden vaihtelu oli vielä laajempaa, vaihteluväli 0-90 \%. Järvien välisen vaihtelun lisäksi eri lajien osuudet saaliista voivat vaihdella myös vuosien välillä samassa järvessä. Ilmiö liittynee 
osaltaan voimakkaan hoitokalastuksen aiheuttamaan lajien välisen kilpailutilanteen muutokseen sekä pyyntiajankohdan, -paikan ja -tehon vaihteluun.

Salakkaa ja ahventa saatiin saaliiksi selvästi vähemmän, tyypillisesti hieman yli $10 \%$ saaliista. Muiden kalalajien (mm. pasuri, kuore, kiiski, sulkava, ruutana) osuus oli keskimäärin noin $4 \%$ saaliista. Peto- ja muiden arvokkaana pidettyjen kalojen (hauki, kuha, isot ahvenet, siika) osuutta ei raportoitu, koska suuressa osassa hoitokalastushankkeita ne vapautettiin, eikä niiden tarkkaa määrää ei ole kirjattu järjestelmällisesti.

\subsection{Saalispotentiaaliarviot}

Tässä työssä käytetyn sisävesien alueellisen ja järvityyppikohtaisen jaottelun perusteella suurin osa järvialasta sijaitsi Etelä- ja "Keski-Suomessa" (Taulukko 2). Järvityypeistä pinta-alaltaan suurimman osuuden muodostivat isot karut ja karuhkot järvet.

Keskimääräinen hehtaarikohtainen kantokyvyn mukainen maksimibiomassa $\left(\operatorname{Bmax}_{1, j, a}\right)$ arvioitiin suurimmaksi Etelä- ja "Keski-Suomen" rehevissä järvissä (Taulukko 2). Keskimääräinen maksimibiomassa-arvio laskee pohjoiseen päin mentäessä ja on pienin isoissa ja keskikokoisissa karuissa järvissä. Keskimääräistä maksimibiomassaa koskeva tieto on vähäistä sekä epätarkkaa ja epätäsmällistä. Siksi sekä keskiarvon mahdollinen vähimmäis- että enimmäisarvo poikkeavat todennäköisimpänä pidetystä arvosta huomattavasti: vähimmäisarvo on korkeintaan $50 \%$ todennäköisimmästä ja enimmäistaso vähintään $100 \%$ todennäköisintä tasoa suurempi (Taulukko 3).

Tuottavimman populaation tason suhteessa kantokyvyn mukaiseen maksimibiomassaan arvioitiin olevan todennäköisimmin noin $50 \%$ maksimitasosta $(\mathrm{p}=0,5)$ (Taulukko 3), mutta myös tähän arvioon lisättiin epävarmuudesta johtuva vaihtelukomponentti. Hetkellisen kalastuskuolevuuden, joka tuottaa saalispotentiaalin (suurimman jatkuvan saaliin biomassan ollessa optimitasolla), arvioitiin aikaisempien särki- ja ahvenpopulaatiotutkimusten perusteella olevan särjellä n. 0,45 ja ahvenella n. 0,35 (Taulukko 3). Aiemman tiedon vähäisyyden vuoksi myös nämä estimaatit ovat melko epätarkkoja (ks. minimi ja maksimi taulukossa 3). 
TAULUKKO 2 Sisävesien pinta-alat alueittain ja järvityypeittäin sekä arvioitu särjen ja ahvenen kantokyvyn mukainen keskimääräinen maksimibiomassa/ha. Min. = arvioitu vähimmäistaso, T.n. = todennäköisimpänä pidetty taso, Maks. = arvioitu enimmäistaso. Aluejako ja järvityypit tarkemmin luvussa 2.2.1.

\begin{tabular}{|c|c|c|c|c|c|c|c|c|c|}
\hline \multirow{3}{*}{$\begin{array}{l}\text { Alue } \\
\text { Järvityyppi }\end{array}$} & \multicolumn{3}{|c|}{ Pinta-ala, ha } & \multicolumn{6}{|c|}{ Maksimibiomassa, $\mathrm{kg} / \mathrm{ha}$} \\
\hline & \multirow{2}{*}{$\begin{array}{l}\text { Min. } \\
-15 \%\end{array}$} & \multirow[t]{2}{*}{ T.n. } & \multirow{2}{*}{$\begin{array}{l}\text { Maks. } \\
+15 \%\end{array}$} & \multicolumn{3}{|c|}{ Särki } & \multicolumn{3}{|c|}{ Ahven } \\
\hline & & & & Min. & T.n. & Maks. & Min. & T.n. & Maks. \\
\hline \multicolumn{10}{|l|}{ Etelä- ja "Keski-Suomi" } \\
\hline Isot karut ja karuhkot & 1054000 & 1240000 & 1426000 & 10 & 20 & 40 & 5 & 10 & 20 \\
\hline Pienet-keskikok. karut ja karuhkot & 357000 & 420000 & 483000 & 10 & 20 & 60 & 5 & 15 & 50 \\
\hline Rehevähköt ja rehevät & 331500 & 390000 & 448500 & 15 & 50 & 180 & 5 & 25 & 85 \\
\hline \multicolumn{10}{|l|}{ Pohjois-Pohjanmaa ja Kainuu } \\
\hline Isot karut ja karuhkot & 172550 & 203000 & 233450 & 5 & 10 & 20 & 1 & 5 & 10 \\
\hline Pienet-keskikok. karut ja karuhkot & 76500 & 90000 & 103500 & 5 & 10 & 20 & 5 & 10 & 20 \\
\hline Rehevähköt ja rehevät & 93500 & 110000 & 126500 & 5 & 25 & 60 & 5 & 15 & 60 \\
\hline \multicolumn{10}{|l|}{ Lappi "särkialue" } \\
\hline Isot karut ja karuhkot & 76500 & 90000 & 103500 & 1 & 5 & 10 & & & \\
\hline Pienet-keskikok. karut ja karuhkot & 42500 & 50000 & 57500 & 5 & 10 & 20 & & & \\
\hline rehevähköt ja rehevät & 59500 & 70000 & 80500 & 5 & 15 & 60 & & & \\
\hline \multicolumn{10}{|l|}{ Lappi "ahvenalue" } \\
\hline Isot karut ja karuhkot & 170000 & 200000 & 230000 & & & & 1 & 5 & 10 \\
\hline Pienet-keskikok. karut ja karuhkot & 64600 & 76000 & 87400 & & & & 1 & 5 & 10 \\
\hline Rehevähköt ja rehevät & 80750 & 95000 & 109250 & & & & 5 & 10 & 25 \\
\hline
\end{tabular}

TAULUKKO 3 Saalispotentiaalin arvioinnissa käytetyt parametrien p ja F arvot (ks. Luku 2.2.2). Minimi = arvioitu vähimmäisarvo, T.n. = todennäköisimpänä pidetty arvo, Maksimi $=$ arvioitu suurin mahdollinen arvo.

\begin{tabular}{lccccccc}
\hline \multirow{2}{*}{ Parametri } & \multicolumn{3}{c}{ Särki } & & \multicolumn{3}{c}{ Ahven } \\
\cline { 2 - 4 } \cline { 6 - 8 } & Minimi & T.n. & Maksimi & & Minimi & T.n. & Maksimi \\
\hline Osuus kantokykybiomassasta, $\mathrm{p} \%$ & 0,35 & 0,50 & 0,65 & & 0,35 & 0,50 & 0,65 \\
Hetkellinen kalastuskuolevuus, F & 0,30 & 0,45 & 0,60 & & 0,25 & 0,35 & 0,50
\end{tabular}

Huomioiden laskelmien lähtötietojen epävarmuudet Suomen sisävesien vuotuinen särkisaalispotentiaali on n. 80 \% todennäköisyydellä välillä 12-26 miljoonaa $(\mathrm{M}) \mathrm{kg}$ ja todennäköisin arvo on noin $19 \mathrm{M} \mathrm{kg}$ (Taulukko 4). Ahvenen saalispotentiaali on vastaavasti 6-12 M kg ja todennäköisin arvo noin $9 \mathrm{M} \mathrm{kg}$ (Taulukko 4).

Kun särjen kaupallisen kalastuksen ja vapaa-ajankalastuksen yhteen laskettu kokonaissaalis on Luonnonvarakeskuksen arvioiden mukaan vaihdellut 2000-luvulla välillä 3-4 M kg, on todennäköisimmän saalispotentiaaliarvion mukaisesti särkisaaliin varaa kasvaa noin viisinkertaiseksi nykyisestä saalistasosta, mikäli kalastus pystytään järjestämään ekologisesti, sosiaalisesti ja taloudellisesti kestävästi. Nykyisestä särkisaaliista kalastavat kaupalliset kalastajat noin viidenneksen, ja tästä saaliista lähes $70 \%$ kertyy hoitokalastuksista.

Luonnonvarakeskuksen arvioima nykyinen sisävesien kokonaisahvensaalis, noin 5-10 $\mathrm{M} \quad \mathrm{kg}$, on samaa suuruusluokkaa kuin arvioitu sisävesien 
ahvensaalispotentiaali. Vapaa-ajankalastajat saavat Luonnonvarakeskuksen tilastojen mukaan nykyisestä ahvensaalista yli $95 \%$.

Valtakunnallisia arvioita sisävesien kalakantojen saalispotentiaalista on tehty melko vähän ja Marjomäen ym. (2016) muikkusaalispotentiaalilaskelmia lukuun ottamatta ne ovat yleensä perustuneet toteutuneisiin tai arvioituihin kalasaaliisiin (mm. Lind 1974, Anttila 1976, Ranta \& Lindström 1989, Setälä ym. 2011) sekä hoitokalastushankkeiden poistokalastusten tuloksiin (mm. Jeppesen \& Sammalkorpi 2002, Puustinen ym. 2017). Setälä ym. (2011) arvioivat sisävesien särkikalapotentiaaliksi hoitokalastussaaliiden perusteella noin 700 000-1 000000 kiloa vuodessa. Luonnonvarakeskuksen työryhmän (Anonyymi 2019b) esittämän arvion mukaan Suomen sisä- ja rannikkovesien särkikalapotentiaalia voisi olla 50 miljoona kiloa. Tarkempia alueellisia saalispotentiaaliarvioita on tehty särkikalojen osalta $\mathrm{mm}$. Koillismaalle, Pohjois-Pohjanmaalle ja Etelä-Lappiin (Deinhardt 2018) ja Satakunnan alueelle osana Pyhäjärvi-instituutin järvikalahankkeita. Deinhardt (2018) arvio Koillismaan, Pohjois-Pohjanmaan ja Etelä-Lapin ekologisesti kestävästä särkisaalispotentiaalista yli 100 ha:n järville oli noin miljoona kiloa vuodessa.

Nyt laaditut saalispotentiaaliarviot ovat melko epätarkkoja (Taulukko 4). Luotettavampien arvioiden saaminen edellyttäisi ahvenen ja särjen tuotantobiologian syvällisempää tuntemista alueellisesti ja tuotantobiologisesti edustavassa järvijoukossa. Keskeisiä lisätutkimusta vaativia seikkoja ovat ensiksikin kalakannan runsaus ja sen luonnollinen vaihtelu sekä kalakannan runsauden ja sen populaatioparametrien vaste kalastuskuolevuuden kasvuun ja sitä kautta kalatiheyden pienenemiseen (kompensatorinen tiheysriippuvuus). Tällä hetkellä ei ole riittävästi tietoa särjen ja ahven kasvunopeuden riippuvuudesta populaation omasta, saati kilpailevien kalalajien runsaudesta. Myöskään yksilökohtaisen ja populaation lisääntymistehon ja kalapopulaation koon välistä riippuvuutta ei tunneta näillä lajeilla juuri lainkaan. Nämä ilmiöt määräävät kuitenkin käytännössä kalatuotannon ja saalipotentiaalin suhteessa kalastustehoon ja kalamäärään. Myöskään ilmaston lämpiämisen vaikutusta e.m. riippuvuuksiin ei tunneta vielä kovin hyvin. Todennäköisesti kuitenkin sekä särjen että ahven tuotanto Suomen leveysasteilla on vahvasti kasvukauden pituudesta ja lämpötilasta riippuvaista. Lisätiedon saaminen edellyttäisi, että edustavan järvijoukon särki- ja ahvenkannan runsautta ja rakennetta (ikä- ja kokojakauma, kasvunopeus, vuosiluokan runsaus) ja (vaihtelevaa) kalastustehoa voitaisiin seurata pitkällä aikavälillä vuodesta toiseen. Kustannustehokkaimmin tämä tapahtuisi osana hoitokalastus- ja kaupallisen kalastuksen kehittämishankkeita.

Tässä hankkeessa kestävää saalispotentiaalia arvioitiin vain kalapopulaatioiden tuotantobiologian näkökulmasta. Saatavilla olevan tiedon perusteella luvussa 2.2.2 laajemmin määritettyjen ekologisen ja sosiaalisten kestävyyden reunaehtojen toteutumista kokonaisuudessaan voidaan arvioida tässä vain hyvin yleisellä tasolla.

Hoito- ja elintarvikekalastus toteutetaan pääsääntöisesti kaupallisen kalastuksen menetelmin, jossa sivusaalis varsinkin rysiä, katiskoita ja vastaavia pyydyksiä käytettäessä voidaan vapauttaa suurelta osin. Useimmissa hoitokalastushankkeissa petokalojen ja muun arvokkaan sivusaaliin vapauttaminen on toiminnan perusedellytys. Pyynnin aiheuttama rasituksen tai muutoin havaitsemattoman kuolleisuuden vaikutuksista särjen ja ahvenen kalastuksessa ei ole tietoa. 
Hoitokalastuksia ja särkikalakantojen säätelyä käytetään laajasti järvien hoitokeinona, jossa pyritään kalayhteisön runsautta ja koostumusta säätelemällä vaikuttamaan ravinteiden kiertoon ja muun eliöyhteisön rakenteeseen sekä saavuttamaan näin kohentunut ekologinen tila. Hoitokalastusten ei ole havaittu aiheuttavan huomattavia haitallisia vaikutuksia järviekosysteemeihin; hankkeiden tavoitteena on järviekosysteemien ekologisen tilan parantaminen ja sen myötä myös ekologisesti/biologisesti kestävän kalavarojen hyödyntämisen edellytysten edistäminen. Hoito- ja elintarvikekalastuksen kohteena olevien särkikala- ja ahvenkantojen geneettisen rakenteen muutoksista ei Suomen sisävesiltä ole tutkimustuloksia, joten mahdollisia vaikutuksia intensiivisen kalastuksen kohteena olevien populaatioiden geneettisiin ominaisuuksiin ei pystytä arvioimaan.

Sosiaalisen kestävyyden reunaehdot, esim. pyynnistä johtuvan mahdollisen häiriön sietäminen ja epäilykset siitä, että tehokas kalastus vähentää sivusaaliina saatavien arvokalojen runsautta, vaihtelevat tapauskohtaisesti. Tehokas hankkeen tavoitteita ja menetelmiä koskeva tiedottaminen sekä kalastusnäytökset ja saalistilastojen julkisuus parantanevat tehokkaankin kalastuksen siedettävyyttä. 
TAULUKKO 4 Särjen ja ahvenen saalispotentiaali hehtaaria kohden ja kokonaismäärä alueittain ja järvityypeittäin. Sarakkeessa K.A. on arvioiden keskiarvo (paras arvio) ja sarakkeissa $10 \%, 25 \%, 75 \%$ sekä $90 \%$ arvot, joita pienempi saalispotentiaali on vastaavalla todennäköisyydellä, kun huomioidaan taulukoissa 2 ja 3 esitetyt lähtötietojen epävarmuudet. Saaliin voidaan arvioida olevan 80 \% todennäköisyydellä niiden arvojen välillä, jotka ovat sarakkeissa $10 \%$ ja 90 \% ja todennäköisyydellä 50 \% niiden lukujen välillä, jotka ovat sarakkeissa $25 \%$ ja 75 \%

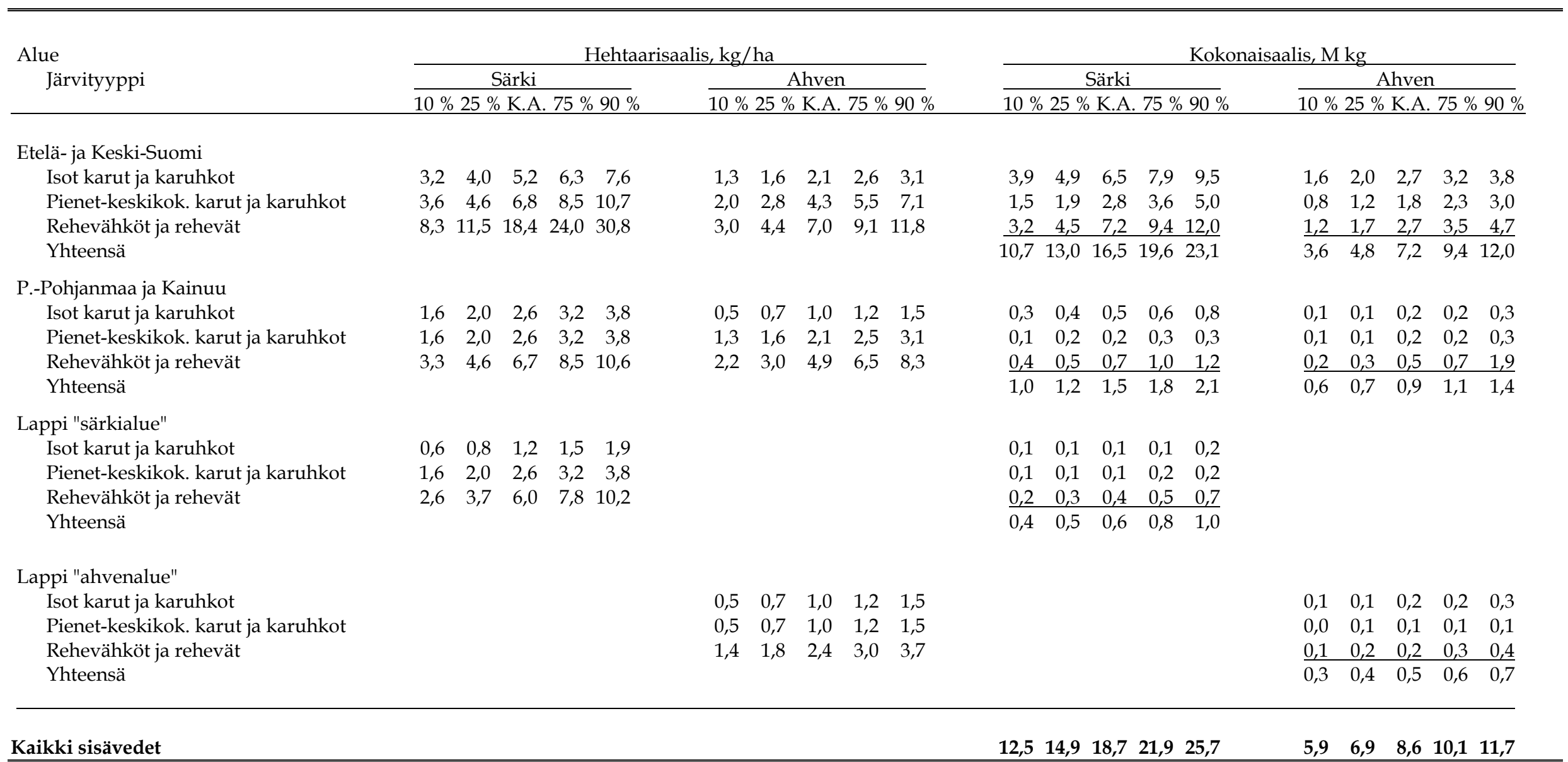




\subsection{Kalastajakumppanien haastattelut}

Haastatteluihin osallistui hankkeen viisi kalastajakumppania, joista kolme tekee pääasiassa hoitokalastuksia ja kaksi kalastaa särkikaloja tai on suunnitellut särkikalojen kalastusta kohdennetusti elintarvikkeeksi muun kalastuksen sesonkiluontoisena lisänä.

Kalastajien toimintasäteessä oli paljon vaihtelua toimijoiden välillä. Osa kalastaa vain asuinpaikkansa lähivesillä 10-100 km säteellä osan liikkuessa laajalti erityisesti hoitokalastusurakoiden perässä ympäri Suomea sekä myös ulkomailla. Hoitokalastuksia pääasiallisesti tekevien toimijoiden toimintasäde oli näin selvästi laajempi kuin elintarvikepyytäjien, jotka kalastivat särkikaloja samoilla lähivesillä, joilla toimivat muutenkin.

Särkikalojen pyynti jakautuu pääasiallisesti kevät- ja syksysesonkiin, jotka eroavat toisistaan pyyntitekniikan ja keston suhteen. Haastatellut toimijat käyttivät kevätpyynnissä pääasiassa tiheäsilmäisiä hoitokalastusrysiä. Kevätsesongin pituus on joitakin viikkoja heti jäiden lähdön jälkeen, sillä elintarvikkeeksi pyydettävän kalan makuhaittojen todennäköisyys lisääntyy veden lämmetessä. Hoitokalastusyrittäjät käyttivät syyspyynnissä tiheäsilmäistä nuottaa ja pitävät nuottausta tehokkaimpana parveutuneiden särkikalojen pyyntimenetelmänä. Kalaparvet etsittiin kaikuluotaamalla, ja yleensä syvänteiden penkoille parveutuneet kalat täsmäpyydettiin nuotalla melko lyhyin vedoin. Syksyllä nuottaus alkoi heti vesien jäähdyttyä ja kalojen parveuduttua ja jatkui aina jäiden tuloon saakka. Joillakin järvillä tiheäsilmäisiä pyydyksiä likaavat ja tukkivat piilevät haittasivat syysnuottausta. Osa haastatelluista oli kokeillut myös särkien katiskapyyntiä, mutta he kokivat katiskat liian tehottomiksi niiden vaatimaan kalusto- ja työmäärään nähden, eikä kukaan haastatelluista pyydä niillä tällä hetkellä aktiivisesti. Katiskapyyntiä pidettiin kuitenkin sopivissa olosuhteissa potentiaalisena särkien ja ahventen pyyntimenetelmänä, ja keskusteluissa ilmeni, että jotkut kalastajat käyttävät katiskoja aktiivisesti.

Pääasiassa hoitokalastusta tekevillä toimijoilla ei ole ollut ongelmia kalaan pääsemisen kanssa, sillä vesialueen omistajat (kalastusoikeuden haltijat) tilaavat heidät yleensä kalastamaan. Erään haastatellun mukaan hoitokalastusta käytetään jonkin verran "keppihevosena" lupien saamiseen osakaskunnilta. Yleensä vesialueiden omistajat näkevät toiminnan kalakannan ja vesistön tilan parantamiseen tähtäävänä, ja kalastuslupia saadaan melko hyvin, jos särkikalat ja muut ei-toivotut saaliskalat poistetaan vesistöstä. Hoitokalastushankkeissa on usein ehtona kaikkien petokalojen vapauttaminen. Osa toimijoista kalasti kaupalliseen kalastukseen myönnetyillä luvilla, jotka oikeuttivat myös sivusaaliina tulleiden petokalojen talteenoton. Tällaisen toimintamallin koettiin parantavan kalastuksen kannattavuutta, ja se nähtiin yhtenä hyvänä keinona lisätä "normaalien" kalastajien kiinnostusta hoitokalastukseen.

Osalla toimijoista on kuitenkin ollut vaikeuksia lupien saamisessa elintarvikepyyntikokeiluihin. Eräiden haastateltujen mukaan vastustusta saattaakin 
tulla erityisesti silloin, kun lupia haetaan pelkästään elintarvikekokoisten särkikalojen kalastukseen. Toisaalta osa toimijoista kalastaa särkikaloja tällä hetkellä kaupalliseen kalastukseen tarkoitetuilla luvilla ilman vesiensuojelutavoitteita, yhteisymmärryksessä vesialueen omistajien kanssa. Toimintatavoissa ja lupien saatavuudessa on siis paljon alueellista ja toimijakohtaista vaihtelua.

Kaikki toimijat tunnistivat useita kalastuskohteeksi potentiaalisia järviä omalta lähialueeltaan, mutta epävarmuus siitä, onko järvissä riittävää määrää elintarvikkeeksi sopivaa kalaa (särki, lahna), nousi usein esiin. Toimijat pitivät yhtä vähintään 1000 hehtaarin järveä tai useampaa muutaman sadan hehtaarin järveä riittävän suurena alueena kannattavalle elintarvikepyynnille. Toisaalta kalastuksen todettiin voivan olla erittäin kannattavaa ja helposti järjestettävissä pienillä isompiin reittivesiin kytköksissä olevilla vesialueilla, joihin särkikalat pakkautuvat keväällä ennen kutuaikaa. Tällaisten vesien saalispotentiaalin arviointia pidettiin kuitenkin ongelmallisena, koska kalojen alkuperää ei tunneta.

Osa haastatelluista toimijoista, erityisesti pitkään hoitokalastusta tehneet, pystyivät arvioimaan kilomääräisiä saalispotentiaaleja toiminta-alueensa järville, mutta osalla ei ollut kovin selvää näkemystä kalastamiensa vesien tai lähialueen järvien saalispotentiaalista. Ylipäätään kalastajat korostivat järvien vaihtelevan paljon niin kalakannan runsauden kuin rakenteenkin puolesta, joten mitään selkeitä yleisiä erityisesti elintarvikekalan pyyntiin sopivien järvien tunnusmerkkejä (esim. rehevyysaste) ei ole helppoa nimetä. Osa toimijoista oli sitä mieltä, että karuhkoissa suurehkoissa järvissä särkikalojen keskikoko on suurempi kuin pienissä rehevissä järvissä, kuten myös osassa pitkään tehokkaasti hoitokalastetuissa kohteissa.

Haastateltujen mukaan potentiaalisimmille järville (yleensä isompia järviä) pääsee yleensä hyvin kaluston puolesta. Esimerkiksi veneenlaskuluiskia on yleensä melko hyvin tarjolla. Lisäksi hoitokalastajilla on käytössään helposti siirreltävää nuottakalustoa, jolla myös pienten kohteiden tehokas kalastus onnistuu tarvittaessa. Pienillä järvillä toimittaessa voi kuitenkin olla haasteita suurten kalamäärien purkamisessa veneestä edelleen kuljetettavaksi ja toiminta saattaa aiheuttaa ristiriitaisia tunteita ranta-asukkaissa.

Pienin kannattava saalis vaihteli jonkin verran toimijoiden välillä, mutta nykyisillä elintarvikekalan hinnoilla $(0,5-1 \quad € / \mathrm{kg}) \quad 500-600 \mathrm{~kg}$ päiväsaalis elintarvikkeeksi kelpaavaa kalaa on alarajoilla hoitokalastuskalustolla tehtävässä pyynnissä. Hoitokalastajien maksimipäiväsaaliit nykyisellä kalustolla ilman kalojen lajittelutarvetta ovat muutamista tonneista aina kymmeneen tonniin saakka. Elintarvikkeeksi kalastavilla toimijoilla kalastus on kannattavaa pienemmillä saalismäärillä kuin hoitokalastajilla. Vuotuiset kokonaissaaliit voivat olla samaa tasoa suurimpien päiväkohtaisten hoitokalastussaaliiden kanssa. Haastattelujen perusteella toimijoiden välillä on isoja eroja toiminnan kulurakenteessa riippuen toiminta-alueen laajuudesta ja käytetystä kalustosta.

Haastatellut hoitokalastajat eivät yleensä lajittele saalistaan, vaan kalat viedään rantaan veneessä, josta ne lastataan eteenpäin kuljettavaksi. Osa haastatelluista hoitokalastustoimijoista tekee satunnaisesti yhteistyötä jalostajien kanssa erityisesti kohteissa, joissa iso osa saaliista voi olla jalostukseen kelpaavaa. Tällöin kalastajat sopivat etukäteen jalostajan kanssa kalojen toimittamisesta. Elintarvikkeeksi pyytävät toimijat lajittelevat kooltaan jalostukseen sopivat kalat yleensä jo veneessä, mutta 
tällöin kalamäärät ovat pienempiä. Kalojen veneessä tapahtuvan lajittelun lisäksi eräs toimija on testannut lajittelevia paneeleja rysien perissä, jolloin pienet jalostukseen kelpaamattomat kalat tai ei-toivotut lajit (esim. kuore suurina määrinä) eivät jää pyydyksiin. Kalojen keräämistä ja sumputtamista pidettiin hankalana isojen saaliiden kohdalla, sillä kalojen lajittelun ja siirtelyn arveltiin todennäköisesti aiheuttavat kuolleisuutta. Toisaalta sitä pidettiin potentiaalisena toimintatapana, jos käsiteltävät kalamäärät ovat kohtuullisia ja sumput sijaitsevat lähellä pyyntialuetta tai pyydyksiä.

Toimijat eivät pitäneet saaliin jäähdyttämistä ja kylmäketjun varmistamista ongelmana, jos saalis pysyy sadoissa kiloissa tai jos tätä suuremmat saaliit saadaan lajiteltua veneessä. Yksittäiset isot saaliit ovat kuitenkin ongelmallisia jatkokäsittelyn kannalta, sillä tonnien sekasaaliin jäähdyttäminen ei onnistu kalastukseen nykyisin käytettävällä kalustolla. Kaikki haastatellut toimijat olivat sitä mieltä, että toimivin ratkaisu nykyisellä toimintamallilla olisi, että kalastaja tuo kalat rantaan ja joku muu taho hoitaa kalojen jatkokäsittelyn ja kuljetuksen. Osa toimijoista piti lisätyövoiman palkkaamista kalojen lajitteluun ja kuljettamisen mahdollisena, jos kalasta saatava korvaus on riittävän suuri. Yhtenä toimintamallina esitettiin, että hoitokalastusten tilaaja (osakaskunta, yhdistys) lajittelisi saaliin rannassa ja hoitaisi elintarvikkeeksi sopivan kalan eteenpäin saaden näin tuloja omaa toimintaansa. Ylipäätään lyhyt ja kiivas sesonki erityisesti keväällä (elintarvikekalan pyyntiaika vain viikkoja) hankaloittaa toimintaa etenkin pienten toimijoilla, joilla on rajoitetusti kalustoa ja työvoimaresursseja. Esimerkiksi uusien kohteiden etsiminen ja suuremmilla vesillä kalapaikkojen löytäminen voivat tuottaa hankaluuksia.

Elintarvikkeeksi soveltuvan kalan markkinoiden ja jalostajien tuntemus oli kahtalainen. Osa kalasti "alihankintana" jalostajalle, jolloin saaliille oli varmat markkinat tiedossa. Hoitokalastajilla tilanne vaihteli enemmän: osa saaliista saatetaan hakea elintarvikekäyttöön, mutta usein isot sekasaaliit menevät lajittelemattomina turkistarhoille tai kompostiin. Toimijoilla on oltava kaloille joku sijoituspaikka tiedossa järvelle lähtiessä, koska isoja määriä (tuhansia kiloja) ei voi säilöä tai alkaa kysellä kiinnostuneita vastaanottajia saaliin ollessa jo rannassa. Joillakin isompien asutuskeskusten lähellä sijaitsevilla hoitokalastuskohteilla kalaa on jaettu rannassa ilmaiseksi halukkaille. Menekki on ollut parhaimmillaan satoja tai jopa tuhansia kiloja päivässä.

Haastateltavilta kysyttiin haastattelun lopuksi heidän näkemyksiään tulevaisuuden tieto- ja tutkimustarpeista. Lähes kaikki toimijat olivat sitä mieltä, että saalispotentiaalilaskelmat ovat toiminnan kannalta tärkeitä, ja jatkossa toivottiin vielä tarkempia, järvikohtaisia arvioita erityisesti särkikalakantojen tilasta ja rakenteesta. Näiden tietojen avulla kalastajat voisivat kartoittaa potentiaalisia kalavesiä etukäteen ja tehdä kokeiluja lupaavimmissa kohteissa. Uusien kohteiden testaamista vaikeuttaa epävarmuus kalakannasta ja sesonkien lyhyys (erityisesti kevätpyynti), jolloin etenkään pienillä toimijoilla (1-2 kalastajaa, rajoitettu kaluston määrä) ei ole mahdollisuutta laajoihin kokeiluihin. Saalispotentiaalitiedon arveltiin myös auttavan lupaneuvotteluissa, mutta toisaalta toivottiin myös apua käytännön toimien järjestämiseen ja vesille pääsyn helpottamiseen. Lisäksi toimijoita kiinnostivat särjen kasvu ja kalastuksen vaikutukset siihen sekä se, millaisella kalastuspaineella saataisiin paras saalis eri vesistöissä. Myös lahnan ja särkien liikkeet sekä toimijoiden mielestä mahdollisesti varsin paikallisten särkikalakantojen kalastuspaineen sieto erityisesti 
isommissa vesistöissä askarruttivat. Pyydykset ja niiden kehitys nousivat myös esille. Erityisesti pyydysten valikoivuuden ja lajittelujärjestelmien kehittäminen olisi tarpeen, jos kalastetaan vain elintarvikkeeksi. Tiedon jakamista eri toimijoiden (kalastajat, tutkimus, jalostajat, vesialueen omistajat) välillä pidettiin myös tärkeänä toimialan kehittymisen kannalta.

\subsection{Työpaja lahnan saalispotentiaalista}

Hankkeessa kerätyn tiedon perusteella todettiin lahnan osalta, että vähäisen ja hyvin vaihtelevan tiedon perusteella ei pystytä tuottamaan saalispotentiaaliarvioita sellaisella tarkkuudella, että arvioista olisi mitään käytännön hyötyä. Yksityiskohtaisia tietoja kalastuksen vaikutuksesta lahnakantaan on saatavilla mm. Tuusulanjärveltä (Malinen ym. 2017, Ruuhijärvi ym. 2017) ja muutamista muista hoitokalastushankkeista eteläisestä Suomesta. Tilanteen ja tiedon tason selvittämiseksi järjestettiin työpaja osana Särkikalat ja kiertotalous -seminaaria Jyväskylässä 28.11.2018. Työpajan tavoitteena oli saada käsitys siitä, voidaanko lahnan saalispotentiaalia arvioida luotettavasti ja miten potentiaalisia vesistöjä voitaisiin tunnistaa. Lahnalla on tällä hetkellä kysyntää elintarvikkeeksi, mutta sen saatavuus ja potentiaali ovat epäselviä. Työpajaan osallistui tutkijoita, kalastaja sekä kalavesien hoidosta vastaavia henkilöitä.

Tällä hetkellä lahnaa saadaan sisävesiltä pääasiassa hoitokalastuksissa sekä muun pyynnin sivusaaliina (verkkokalastus, rysäpyynti, muikun nuottaus ja troolaus). Kaupallisten kalastajien saalis sisävesiltä on ollut keskimäärin 290000 kg/vuosi (Kuva 8) (Luonnonvarakeskus 2019). Vapaa-ajan kalastajien saaliiksi on arvioitu viime vuosina keskimäärin 1100000 kg/vuosi (kuva 8). Vapaa-ajan kalastajien saalis koostunee pääasiassa perinteisestä kutupyynnistä verkoilla ja pienillä rysillä sekä verkkokalastuksen ja muiden pyyntimuotojen sivusaaliista. Työpajan osallistujilta kysyttiin näkemyksiä tyypillisistä lahnasaaliista pyydystyypeittäin. Verkkokalastuksen saaliit ovat yleensä kappale- ja kilomääräisesti pieniä ja koostuvat lähinnä esimerkiksi kuhan talviverkkopyynnin sivusaalista. Keväisessä kutupyynnissä harvoilla verkoilla saaliit voivat olla isompia, mutta kokonaissaalis jäänee alhaiseksi. Isojen lahnojen pyynti harvoilla riimuverkoilla on oma perinteinen pyyntimuotonsa, mutta nykyään lähinnä vapaa-ajankalastajien harrastus. Lahnoja saadaan myös muun suomukalan rysäpyynnissä sivusaaliina. Rysäpyynnin päiväkohtaiset saaliit ovat yleensä pieniä, mutta kauden mittaan saalista voi kertyä satoja tai joitakin tuhansia kiloja. Rysäsaaliiden keräilyyn ja hyödyntämiseen liittyen on Kaakkois-Suomen ammattikorkeakoululla (XAMK) meneillään sumputuskokeiluja, joiden alustavat tulokset vaikuttavat lupaavilta. 


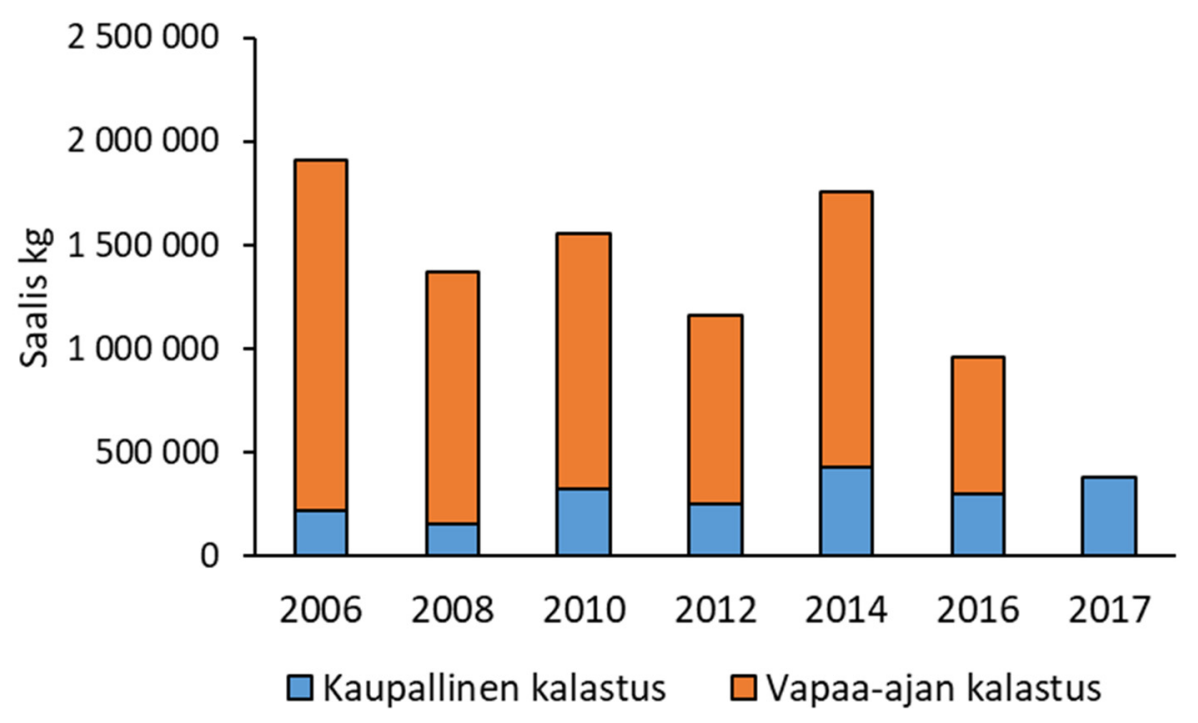

KUVA 8 Kaupallisten kalastajien vapaa-ajankalastuksen saalis vuosina 2006-2017 (Luonnonvarakeskus 2019).

Hoitopyyntirysien lahnasaaliit voivat olla keväällä satoja kiloja päivässä (useita rysiä pyynnissä), mutta sesonki on yleensä tällöin lyhyt (2-4 viikkoa). Hoitonuottauksissa päiväsaaliit voivat olla myös satoja ja jopa joitakin tuhansia kiloja, mutta saaliin vaihtelu on yleensä suurta. Isoja ison kalan parvia jää satunnaisesti saaliiksi, eikä niiden saamista ei voi luotettavasti ennakoida. Hankkeessa kerätyn aineiston (48 järven tiedot saaliin koostumuksesta) ja hoitokalastusyrittäjän arvion perusteella hoitokalastussaaliissa on keskimäärin noin $20 \%$ lahnaa, mutta järvien välinen vaihtelu osuudessa voi olla todella suurta (0-90\%).

Työpajan osallistujilta kysyttiin, millaiset järvet ovat sopivimpia lahnan kalastukseen ja voiko niitä tunnistaa joidenkin ominaisuuksien perusteella. Osallistujat pitivät parhaina matalia ja kirkkaahkoja järviä, joissa on runsaasti pohjaeläimiä ravinnoksi, mikä mahdollistaa kalojen nopean kasvun. Toisaalta myös rehevissä järvissä voi olla todella paljon lahnaa. Lisäksi suurten järvien matalat lahdet mainittiin potentiaalisina kohteina, joihin lahnat kertyvät tiettyinä aikoina ja voivat olla helpoimmin kalastettavissa. Keskimääräiseksi saalispotentiaaliksi "lahnajärville" arvioitiin noin $10 \mathrm{~kg} /$ ha vuodessa, mutta vaihtelu järvien välillä voi olla suurta.

Työpajaan osallistuneiden näkemys oli, että tyypillisesti lahnakanta koostuu etenkin rehevissä järvissä pienistä yksilöistä, mitä osaltaan tukevat myös hankkeessa kerätyt hoitokalastusten saalisaineistot. Esimerkiksi Karhijärven ja Karvianjärven hoitokalastussaalissa elintarvikekäyttöön soveltuvien yksilöiden määrä oli vähäinen ja pääosa saaliista koostui alle $20 \mathrm{~cm}$ pituisista yksilöistä (Suomi 2018). Toisaalta osallistujat nostivat esiin, että pitkään kalastamatta olleissa rehevissä järvissä voi olla runsaasti suuria vanhoja yksilöitä. Tämä havaittiin esimerkiksi Jyväsjärven hoitokalastushankkeessa, jossa hoitokalastusvaiheen kolmena vuotena saatiin saaliiksi runsaasti myös isoja lahnoja (Jyväsjärvi ym. 2013, Suomi 2018). Työpajan osallistujien näkemyksen mukaan karummissa järvissä esiintyy myös varsin kookkaita lahnoja, mutta niiden tiheys on yleensä alhainen. 
Työpajaan osallistuneiden kokemusten mukaan suurimmat lahnayksilöt häviävät saaliista melko nopeasti intensiivisellä kalastuksella, mutta elintarvikkeeksi hyödynnettävän kokoista kalaa voisi olla saatavissa sopivissa oloissa. Lahnan kasvu on osin riippuvaista (särki)kalakannan tiheydestä, ja on selviä viitteitä siitä, että yksilöiden kasvu paranee, jos särkikalojen määrä vähenee selvästi pysyvämmin (Malinen ym. 2017, Ruuhijärvi ym. 2017).

\subsection{Säkylän Pyhäjärvi - kalastajahaastattelut}

Pyhäjärvi-instituutti toteutti hankkeen aikana sarjan Säkylän Pyhäjärvellä toimiville kaupallisille kalastajille suunnattuja haastatteluja. Haastatteluiden tarkoituksena oli kartoittaa Säkylän Pyhäjärven kaupallisten kalastajien näkemyksiä kalataloudesta, sen tulevaisuudesta alueella ja eri kalalajien saalispotentiaalista sekä nykyisen kalastuksen kestävyydestä. Säkylän Pyhäjärvellä kaupallinen kalastus on ollut pitkään poikkeuksellisen hyvin järjestäytynyttä, ja sieltä saadut kokemukset voivat palvella koko maan kalataloutta. Haastatteluista tehtiin erillinen raportti (Liite 2).

Haastattelut toteutettiin henkilöhaastatteluina vuoden 2018 touko- ja kesäkuun aikana. Haastatteluihin osallistui viisi keskeistä toimijaa. Säkylän Pyhäjärvellä toimi raportin kirjoitushetkellä kolme aktiivista nuottakuntaa. Kahden nuottakunnan edustajat saatiin mukaan haastatteluun, yhden yhteyshenkilö kieltäytyi. Pyhäjärven kalastusalueen mukaan Pyhäjärvellä toimi vuonna 2018 50-60 kaupallista kalastajaa, joista 22 on ns. päätoimisia kalastajia.

Kalastajat arvioivat myös, mitkä olisivat tulevaisuudessa tärkeimpiä lajeja heidän omassa kalastuksessaan. Kysymyksenasettelussa annettiin vaihtoehdoiksi viisi kalalajia (ahven, särki, muikku, siika ja kuore), joista tuli asettaa kolme keskeisintä lajia tärkeysjärjestykseen. Muikku, ahven ja särki koettiin merkittävimmiksi lajeiksi tulevaisuudessa. $40 \%$ kalastajista arvioi, että täplärapu on jatkossa mainittuja kalalajeja tärkeämpi.

Kalastuksen kestävää saalistasoa arvioitiin lajikohtaisesti ahvenen, särjen, kuoreen, siian ja muikun osalta. Ahvenen osalta kalastajien näkemykset olivat saman kaltaisia yhtä vastaajaa lukuun ottamatta: saalismääriä ei tulisi nykyisestä enää kasvattaa (Kuva 9). Myöskin siian saaliin ajateltiin olevan sopivalla, vaikkakin heikolla, tasolla. Muiden lajien kohdalla vastauksissa oli enemmän hajontaa (Kuva 9).

Kalastajien vastausten keskiarvo verrattiin myös Pyhäjärven kalastusalueen ilmoittamien vuosisaaliiden keskiarvoon vuosilta 2013-2017. Vastaajien vastausten keskiarvot olivat samaa suuruusluokkaa aiempiin saaliskeskiarvoihin verrattuna (kuva 9). 


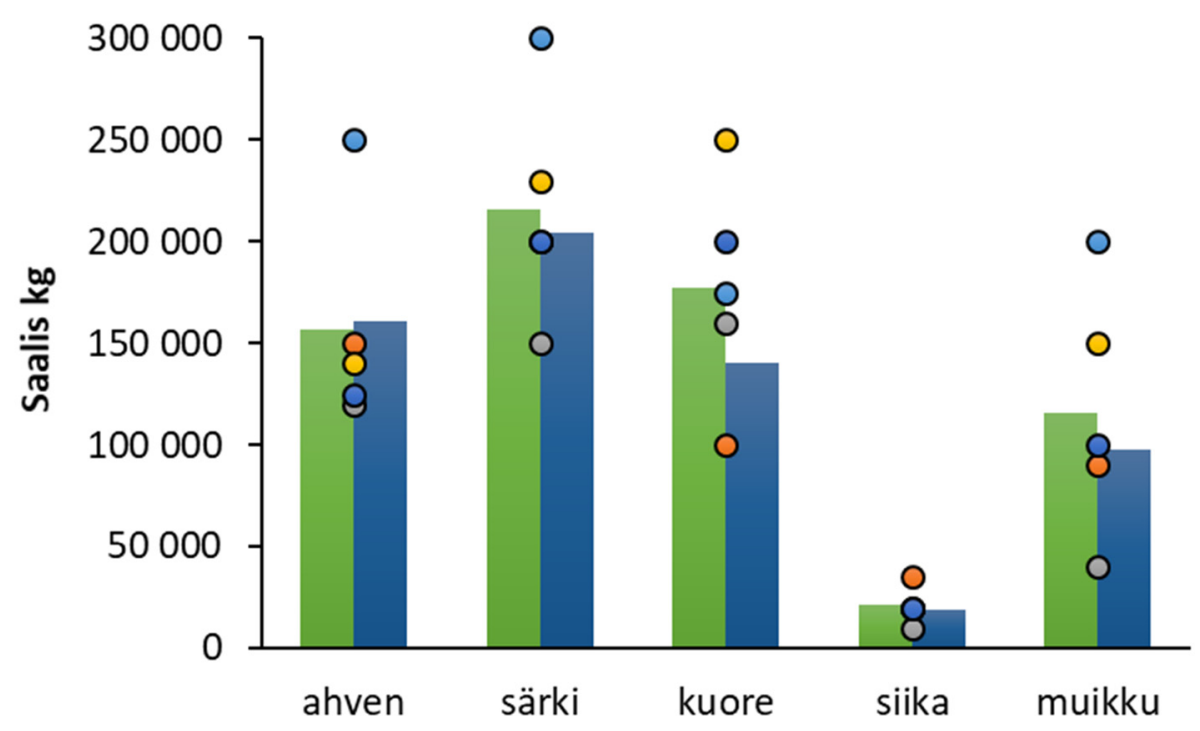

KUVA 9 Kalastajien arvio kestävästä saalistasosta Säkylän Pyhäjärvellä kalalajikohtaisesti vuosittain. Vihreillä palkeilla on kuvattu vastausten keskiarvo. Pallot kuvaavat kalastajien yksittäisiä arvioita. Sininen palkki on arvio kunkin kalalajin vuosisaaliiden keskiarvosta vuosilta 2013-2017 ja perustuvat Pyhäjärven kalastusalueen vuosisaalisarvioihin.

\subsection{Hoitokalastussaaliiden hyödynnettävyys elintarvikkeena}

Vajaasti hyödynnettyjen lajien tehokkaan elintarvikekäytön kannalta on tärkeää tietää, millaista kalaa kalanjalostajat voivat nykyään hyödyntää ja millaisista kaloista (koko- ja lajijakaumat) hoitokalastussaaliit koostuvat. Hoitokalastussaaliiden hyödynnettävyyttä kalanjalostuksessa selvitettiin osana hanketta Iia Suomen pro gradu -tutkielmassa (Suomi 2018).

Hoitokalastussaaliissa yleisesti esiintyvien lahnan, ahvenen ja särjen pituusjakaumia tarkasteltiin neljältä järveltä. Saaliin pituusjakaumia verrattiin kalanjalostajien tuotannossaan käyttämiin kokoluokkiin. Tiedonkeruussa käytettiin tutkimusjärvien hoitokalastusaineistoja sekä haastateltiin kalanjalostajia. Myös eri järvien saaliiden kokojakaumia verrattiin toisiinsa. Tutkielmassa tarkasteltiin myös koeverkkokalastusaineistojen ja hoitokalastusaineistojen laji- ja kokojakaumatietojen samankaltaisuutta.

Hoitokalastussaaliiden eri lajien kokojakaumat vaihtelivat eri järvien ja kalastusvuosien välillä, ja pienten kalojen osuus kasvoi hoitokalastuksen edetessä. Kalanjalostajien haastattelujen perusteella suuri osa hoitokalastussaaliista voitaisiin hyödyntää kalanjalostuksessa (Kuva 10). 

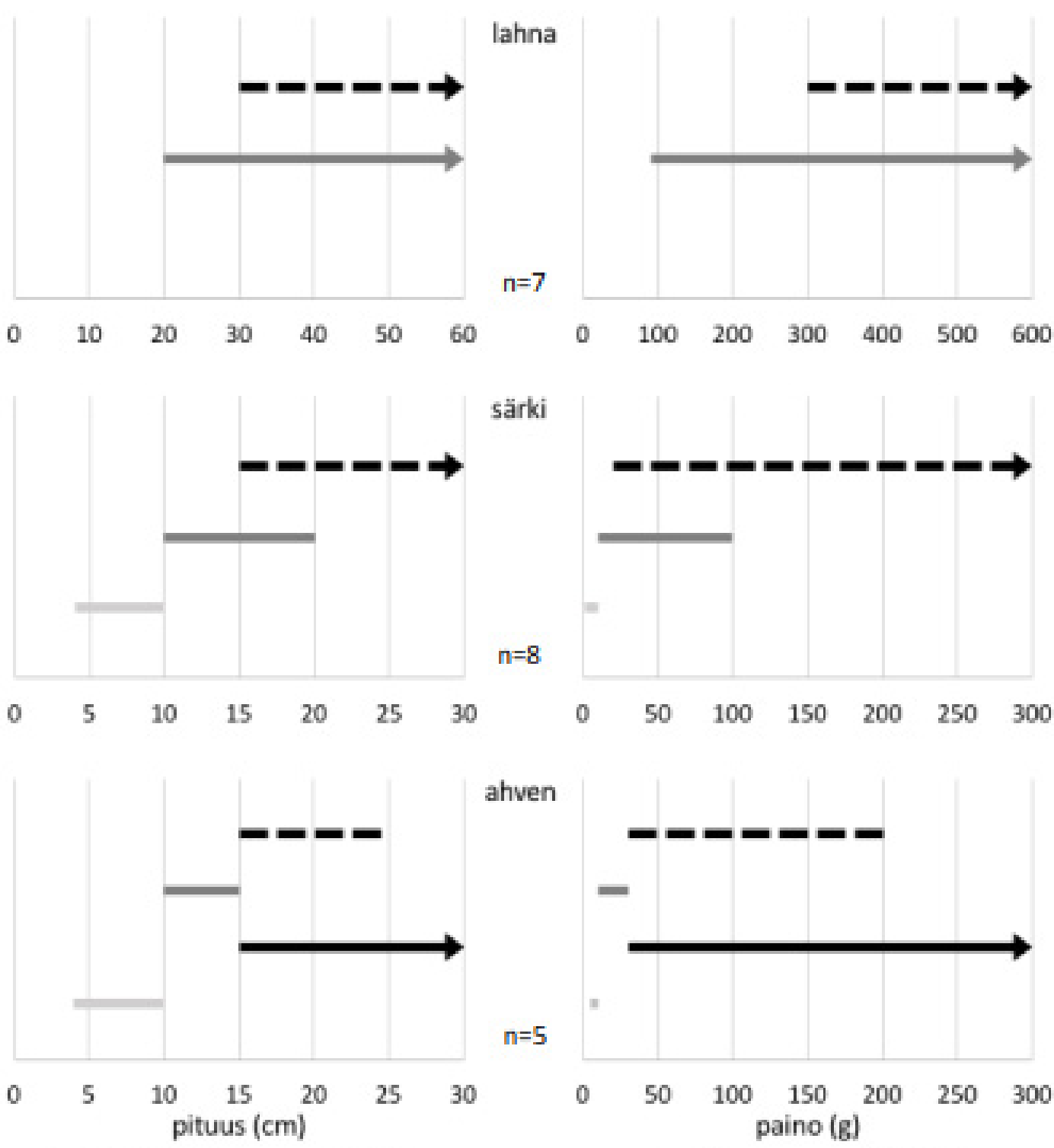

- - kalamassa $=$ säilyke

- filee $=$ kukkokala

KUVA 10 Lahnan, särjen ja ahvenen kokoluokkien (vasemmalla pituus, oikealla paino) soveltuvuus eri tuotteiden valmistuksessa kalanjalostajien haastattelujen perusteella. Nuoli viittaa siihen, ettei kalan koolle ole ylärajaa tuotteen valmistuksen kannalta, n=kysymykseen vastanneiden jalostajien määrä. Kuva teoksesta Suomi (2018).

Pienien saaliskalojen hyödyntäminen on kuitenkin kaikkein vaikeinta, ja niiden osuus hoitokalastussaaliista oli suuri usealla tutkimusjärvellä. Tutkimuksen tulosten perusteella koeverkkokalastusta voitaisiin hyödyntää hoitokalastuksen saalispotentiaalin ennakoinnissa, sillä koeverkkokalastuksen ja hoitokalastuksen saaliiden kokojakaumat olivat samankaltaisia. 


\section{LÄHDELUETTELO}

Anonyymi 2019a. Maximum sustainable yield.

https://en.wikipedia.org/wiki/Maximum_sustainable_yield, haettu 25.3.2019.

Anonyymi 2019b. Särkikalat ovat vesiemme hyödyntämätön aarre. https:// mmm.fi/artikkeli/-/asset_publisher/sarkikalat-ovat-vesiemmehyodyntamaton-aarre, haettu 26.3.2019.

Anttila R. 1976. Sisävesien saalis- ja kalantuotantoarvioita. Vesitalous 2: 20-23.

Deinhardt M. 2018. Vähempiarvoisen kalan arvoketjun kehittäminen Koillismaalla. Hankkeen loppuraportti.

Graham M. 1935. Modern theory of exploiting a fishery, and application to North Sea trawling. ICES J. Mar. Sci. 10: 264-274.

Horppila J. \& Peltonen H. 1994. The fate of a roach Rutilus rutilus stock under an extremely strong fishing pressure and its predicted development after cessation of mass removal. J. Fish Biol. 45: 777-786.

Horppila J., Olin M., Vinni M., Estlander S., Nurminen L., Rask M., Ruuhijärvi J. \& Lehtonen H. 2010. Perch production in forest lakes: the contribution of abiotic and biotic factors. Ecol. Freshwat. Fish 19: 257-266.

Huttunen H. 2018. Kyllä nappaa - Särkikalaa Pohjois-Savosta. Opinnäytetyö, Savonia Ammattikorkeakoulu.

Jeppesen E. \& Sammalkorpi I. 2002. Lakes. Teoksessa: Perrow M.R. \& Davy A. (toim.), Handbook of Ecological Restoration, volume 2, Cambridge Univeristy Press, s. 297324.

Jyväsjärvi J., Immonen H., Högmander P., Högmander H., Hämäläinen H. \& Karjalainen J. 2013. Can lake restoration by fish removal improve the status of profundal macroinvertebrate assemblages? Freshw. Biol. 58: 1149-1161.

Karjalainen J., Leppä M., Rahkola M. \& Tolonen K. 1999. The role of benthivorous and planktivorous fish in a mesotrophic lake ecosystem. Hydrobiologia 408/409: 7384.

Koljonen S., Sammalkorpi I., \& Hellsten S. (toim.) 2019. Vesistökunnostusten seuranta. Suomen ympäristökeskus.

Käyhkö A., Setälä J., Salmi P. 1997. Vajaakäyttöisen järvikalan jalostuksen ongelmat ja kehittäminen. Kalatutkimuksia, Riistan- ja kalantutkimuksia 131: 1-32.

Lappalainen J., Tarkan A.S. \& Harrod C. 2008. A meta-analysis of latitudinal variations in life-history traits of roach, Rutilus rutilus, over its geographical range: linear or non-linear relationships? Freshw. Biol. 53: 1491-1501.

Lind E.A. 1974. Fish production in some Finnish lakes determined on the basis of catch statistics and food coeffiecents. Kalottialueen rauhanpäivät, Rovaniemi.

Luonnonvarakeskus 2019. Kaupallinen kalastus sisävesillä. https://stat.luke.fi/kalaja-riista

Malinen T., Kervinen J. \& Peltonen H. 2017. Tuusulanjärven lahna-, pasuri- ja särkikannat vuosina 2005-2011. Uudenmaan ELY-keskuksen raportteja 56: 51-61. 
Marjomäki T.J., Keskinen T. \& Karjalainen J. 2016. The potential ecologically sustainable yield of vendace (Coregonus albula) from large Finnish lakes. Hydrobiologia 780: 125-134.

Olin M., Rask M., Ruuhijärvi J., Kurkilahti M., Ala-Opas P. \& Ylönen O. 2002: Fish community structure in mesotrophic and eutrophic lakes of southern Finland: the relative abundances of percids and cyprinids along a trophic gradient. J. Fish Biol. 60: 593-612.

Olin M., Rask M., Estlander S., Horppila J., Nurminen L., Tiainen J., Vinni M. \& Lehtonen H. 2017. Roach (Rutilus rutilus) populations respond to varying environment by altering size structure and growth rate. Boreal Env. Res. 22: 119136.

Peltonen H. \& Horppila J. 1992. The effects of mass removal on the roach Rutilus rutilus (L.) stock of Lake Vesijarvi estimated with VPA within one season. J. Fish Biol. 40: 293-301.

Pilke A. (toim.) 2012. Ohje pintaveden tyypin määrittämiseksi. Suomen ympäristökeskus.

Puustinen M., Sammalkorpi M., Tattari S., Ruuhijärvi J., Uusitalo R. \& Väisänen S. 2017. Vesienhoitoa pellossa ja järvessä. Vesitalous 4: 30-34.

Ranta E. \& Lindström K. 1989. Prediction of lake-specific fish yield. Finnish Fish. Res. 8: 113-128.

Rask M. \& Arvola L. 1985. The biomass and production of pike, perch and whitefish in two small lakes in souther Finland. Ann. Zool. Fennici 22: 129-136.

Rask M. \& Ruuhijärvi J. 1990. Pienten järvien kalatutkimukset. Suomen Kalatalous 56: 101-115.

Rask M., Sairanen S., Vesala S., Arvola L., Estlander S. \& Olin M. 2014. Population dynamics and growth of perch in a small, humic lake over a 20-year period importance of abiotic and biotic factors. Boreal Env. Res. 19: 112-123.

Ruuhijärvi J., Rask M., Vesala S. \& Olin M. 2017. Tuusulanjärven kalakantojen muutokset järven kunnostuksen vuosina 1996-2012. Uudenmaan ELY-keskuksen raportteja 56: 45-50.

Salminen M. \& Böhling P. (toim.) 2018. Kalavarojen käyttö- ja hoito: A \& B. Luonnonvarakeskus.

http://urn.fi/URN:ISBN:978-952-326-655-1, http:// urn.fi/URN:ISBN:978-952$\underline{326-657-5}$

Sarvala J., Helminen H., Ripatti J.P., Pruuki V. \& Ruuhijärvi J. 1992. Tehokalastuksen vaikutus Evon Syrjänalusen särkikantaan. Suomen Kalatalous 60: 191-205.

Setälä J., Tarkki V., Mannerla M. \& Vielma J. 2011. Vajaasti hyödynnetyn kalan kaupalliset käyttömahdollisuudet. Riista- ja kalatalouden tutkimuslaitoksen työraportteja 11/2011: 1-30.

Suomi I. 2018. Särki-, ahven- ja lahnasaaliiden koostumus järoikalastuksissa ja erikokoisten kalojen hyödynnettäryys kalanjalostuksessa. Pro gradu -tutkielma, Jyväskylän yliopisto.

Tuunainen P. 1970. Relations between the benthic fauna and two species of trout in some small Finnish lakes treated with rotenone. Ann. Zool. Fennici 7: 67-120. 
Liite 1. Kalastajakumppanien haastatteluissa käytetty haastattelupohja.

Vajaasti hyödynnettyjen kalalajien ekologisesti kestävä saalispotentiaali - toimijoiden haastattelut

Aika ja paikka:

Toimija:

Pääasiallinen toiminta-alue:

Perustietoja toiminnasta:

Kalastettavat kohteet

- Kannattava toimintasäde (noin $\mathrm{km})$ ?

- Minkä verran kalastajan toimintasäteellä on sopivia järviä (myös sellaiset joilla ei kalasteta tällä hetkellä?

- Millaiset järvet sopivimpia (taloudellisesti) kannattavaan poistopyyntiin?

Minimikoko?

- tietty kilomäärä saalista?

- minimi kilohinta ilman tukia?

Saalis Aiheuttaako järville pääsy ongelmia?

- Saalispotentiaaliarvioita ( $\mathrm{kg} / \mathrm{ha}$, tonnia vuodessa), käydään yhdessä läpi tietyt järvet esimerkkeinä

- kokonaissaalis lajeittain, elintarvikkeeksi kelpaava osuus ( $\mathrm{x}-\mathrm{xx} \%)$

- Miten kalastus kannattaisi järjestää kalastajan näkökulmasta?

- Kertapoistot, kiertokalastus, "perinteinen" kalastus (vain tuotto kalastetaan)

- Saaliin rakenteen vaihtelut, onko jotain selkeitä "sääntöjä" minkälaisissa vesissä on esimerkiksi isompaa kalaa/tiettyä lajia?

- Eri kalalajit tulevaisuudessa, mikä näkemys vajaasti hyödynnettyjen (särkikalat, ahven yms) kalakantojen tilanteesta? Muuttuko lajisto/lajisuhteet/kokoluokat?

\section{Pyydykset ja saaliin jatkokäsittely}

- Minkä verran saalista kerralla maksimissaan päivässä/kaudessa tämän hetkisellä kalustolla? Rajoittaako kalakanta, olosuhteet, välineet vai menekki?

- Rysä vs. nuotta vs. katiska. Toiminnan tehokkuus/kätevyys/reunaehdot (eri järvillä eri menetelmät?)

- Talvikalastus jään alta? Kokemuksia/näkemyksiä?

- Pyydykset. Onko kehitystyö viety jo riittävän pitkälle? Jos ei, niin mitä voisi kehittää?

- Saaliin valikointi, onnistuuko pyyntimenetelmillä (pyydykset, paikka, ajoitus) tai veneessä/rannalla?

- -Elintarvikkeeksi kalastettava kala, miten käsittely onnistuu? ○ jäähdytys, verestys yms. laatutekijöiden huomioinen

- Kalojen toimittaminen jalostajille?

- Makuongelmat? Onko järvikohtaisia eroja?

- Onko kalastajilla hyvä käsitys millaista kalaa haluttaisiin elintarvikkeeksi?

- Kohtaavatko kala ja jalostajat? Jos eivät, mitkä suurimmat syyt?

\section{Tulevaisuus}

- Millaista tietoa/tutkimusta/tukea kalastajat kaipaisivat työnsä tueksi? 


\section{PYHÄJÄRVI @instituUtTI}

\section{Raportti Säkylän Pyhäjärven ammattikalastajien haastatteluista}

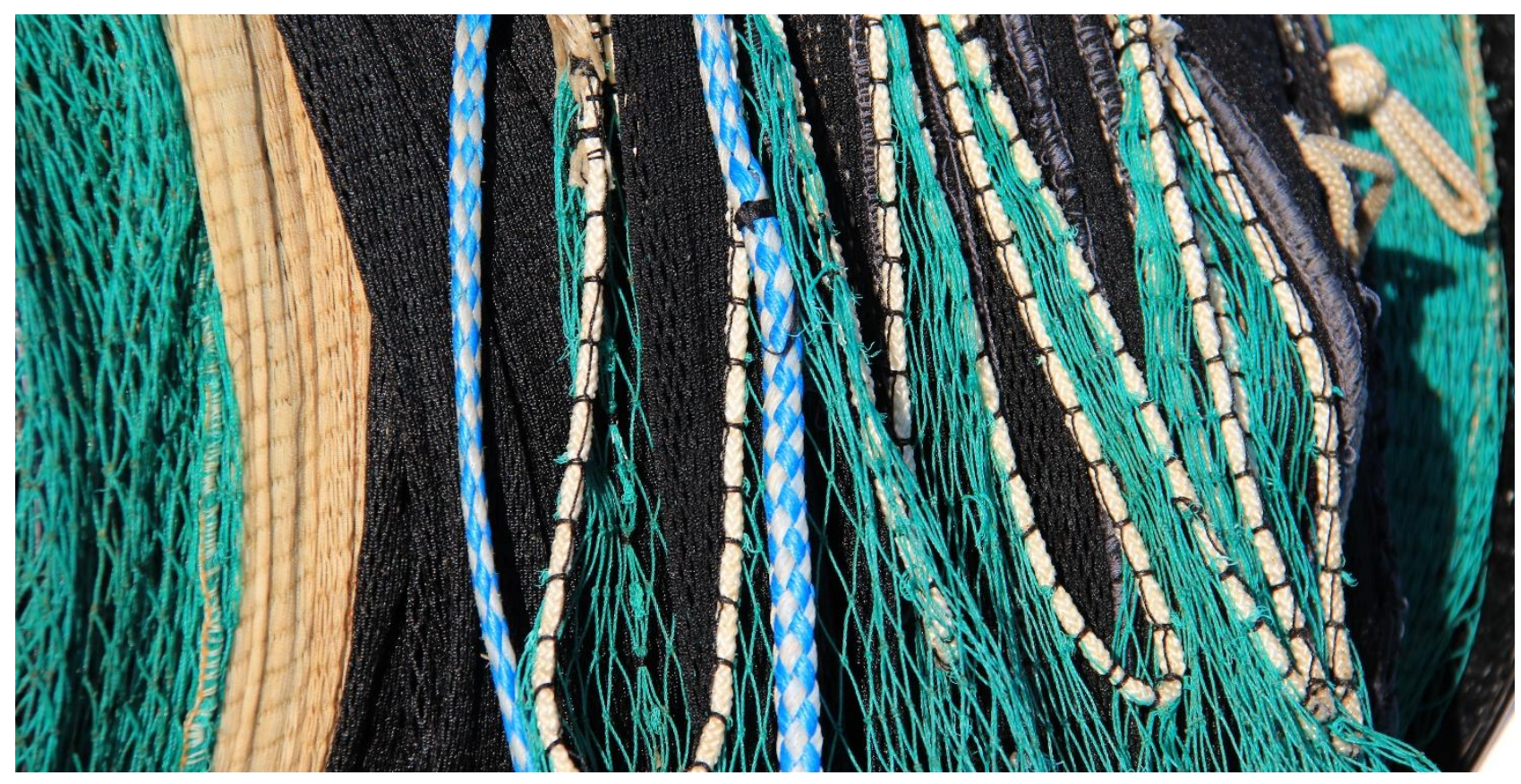

\subsubsection{8 \\ Tero Forsman}

Sisävesien talouslajien ekologisesti kestävän saalispotentiaalin määrittäminen - hanke
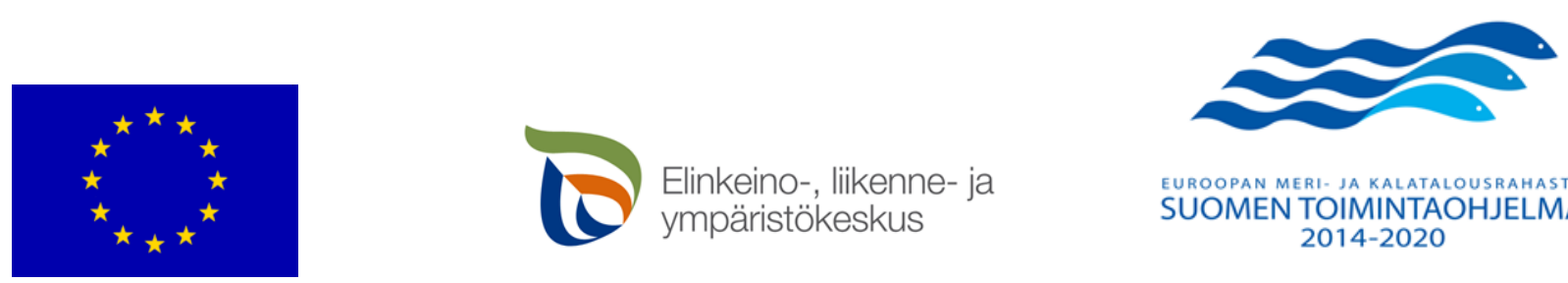


\section{Sisällys}

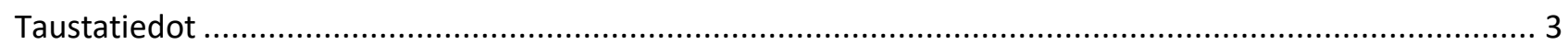

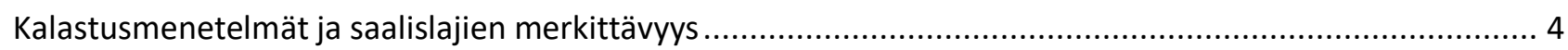

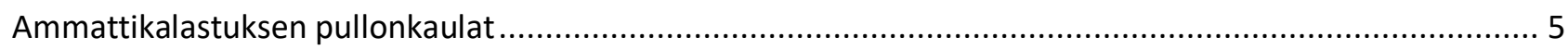

Tyytyväisyys vajaasti hyödynnettyjen kalalajien rahoitusmalliin ......................................................... 5

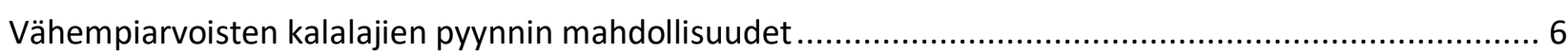

Näkemyksiä Pyhäjärven kalastuksen kehittymiseen ja tulevaisuuteen ....................................................... 6

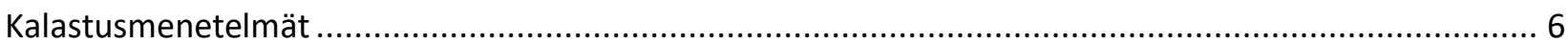

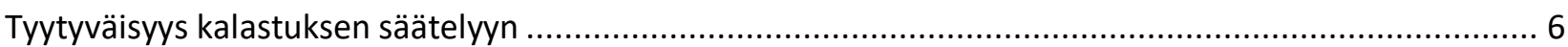

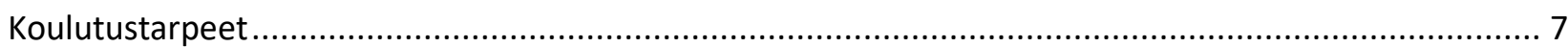

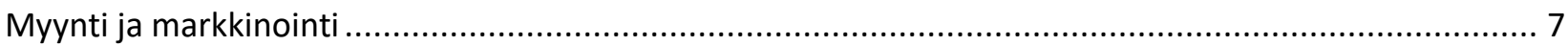

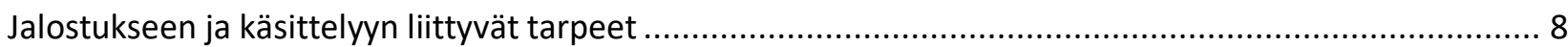

Kiinnostus ja valmius kalastukseen muilla järvillä ............................................................................ 8

Näkemyksiä hoitokalastuksen tarpeellisuuteen ja Pyhäjärven vedenlaatuun ........................................ 8

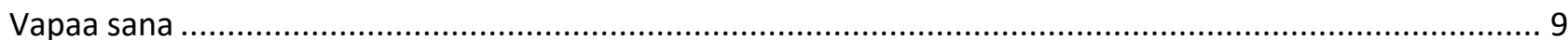




\section{Taustatiedot}

Pyhäjärvi-instituutti toteutti hankkeen aikana sarjan ammattikalastajille suunnattuja haastatteluja. Haastatteluiden tarkoituksena oli kartoittaa Säkylän Pyhäjärven ammattikalastajien näkemyksiä kalatalouteen ja sen tulevaisuuteen alueella. Hankkeen päätoteuttajana toimi Jyväskylän yliopisto. Hanke on osittain rahoitettu Euroopan meri- ja kalatalousrahaston Suomen toimintaohjelmasta.

Haastattelut toteutettiin henkilöhaastatteluina vuoden 2018 touko- ja kesäkuun aikana. Haastatteluihin osallistui viisi keskeistä toimijaa. Säkylän Pyhäjärvellä toimi raportin kirjoitushetkellä kolme aktiivista nuottakuntaa. Kahden nuottakunnan edustajat saatiin mukaan haastatteluun, yhden yhteyshenkilö kieltäytyi. Pyhäjärven kalastusalueen mukaan Pyhäjärvellä toimi vuonna 2018 50-60 ammattimaista kalastajaa, joista 22 on ns. päätoimisia kalastajia. Osa haastatelluista henkilöistä toimi ammattimaisen kalastuksen lisäksi raputaloudessa ja kalanjalostuksessa.

Haastattelu koostui haastatteluosuudesta, jonka lisäksi haastateltavia pyydettiin arvioimaan kalakantojen kestävää saalispotentiaalia arvioimalla pyynnin sopivaa tasoa verrattuna aikaisempiin saalismääräarvioihin (Pyhäjärven kalastusalueen saalisarviot). Tämä osuus toteutettiin käytännössä pyytämällä haastateltavaa arvioimaan haastattelulomakkeessa (Liite 1 ) olevaan tilastoon sopiva taso merkitsemällä se viivalla tai vaihteluvälillä. Raporttiin on lisätty haastattelun yhteydessä tulleita kommentteja. Nämä osuudet on eroteltu muusta tekstistä kursiivilla.

Haastateltujen kalastajien toimeentulosta 40 - $100 \%$ tuli kala- ja raputaloudesta. Haastateltavien keskuudessa keskeisimmät kalastusmuodot suhteessa toimeentuloon olivat rysät, talvinuotta ja ravustus (kuva 1.).

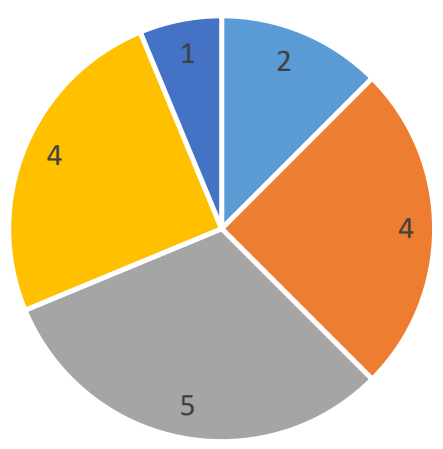

- Avovesinuotta - Talvinuotta - Rysät navustus verkot

Kuva 1. Keskeisimmät ammattikalastajien käyttämät pyydykset Säkylän Pyhäjärvellä suhteessa toimeentuloon. Vastaajien $n=5$.

Avovesinuottaus on Pyhäjärvellä uusi, 2010-luvulla käyttöönotettu, eritoten särjen pyyntiin kohdistettu menetelmä. Myös muita menetelmiä on kokeiltu viime vuosina.

Kurenuottaa kokeiltiin, mutta sen käyttö lopetettiin, kun ahvenia jahtaavia lokkiparvia ei enää näkynyt. Avovesinuotalla tuli vuoden 2017 syksyllä 100000 kg särkeä. Parhaat saaliit saatiin juuri ennen jäiden tuloa. Avovesinuottauksen onnistumisen kannalta loppusyksyllä täytyisi olla kylmää, mutta järven pysyä jäättömänä. Tuulella ei ole muuten väliä, mutta kalastamaan täytyy pystyä. Kirkkaalla ilmalla parveutuvat paremmin, synkkänä eivät parveudu vaan jäävät erilleen. 


\section{Kalastusmenetelmät ja saalislajien merkittävyys}

Kalastajia pyydettiin arvioimaan keskeisten pyyntilajien taloudellista merkittävyyttä. Merkittävimmiksi lajeiksi nousivat muikku, rapu ja särki.

\section{Kalalajien taloudellinen merkitys kalastajalle} 2018

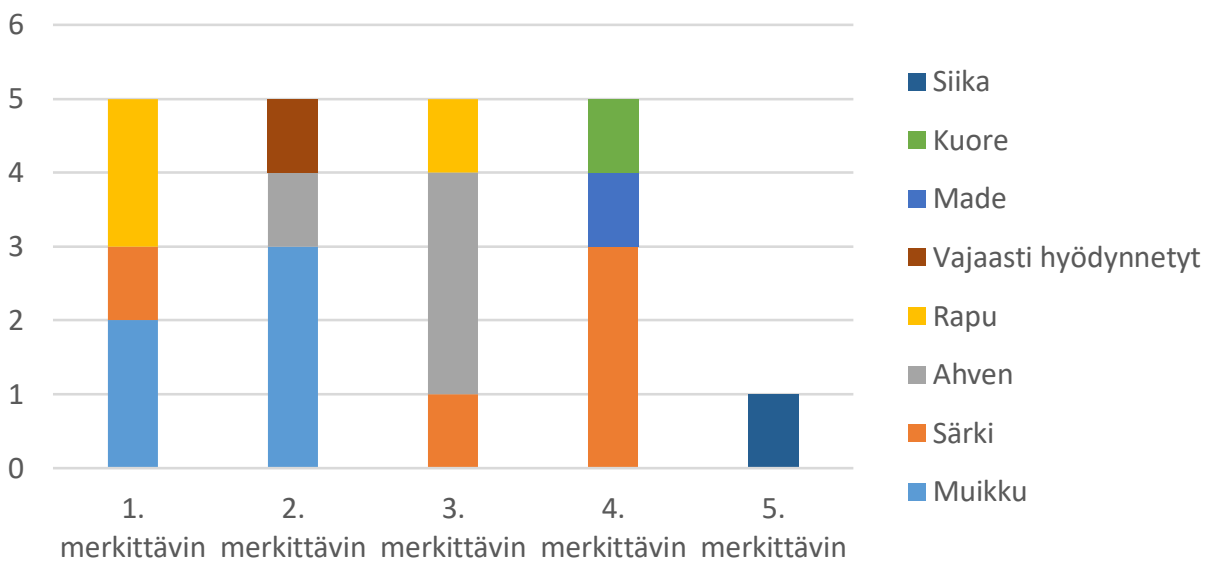

Kuva 2 Säkylän Pyhäjärven kalastajien arvio pyydettävien kalalajien taloudellisesta merkittävyydestä. Y-akselilla on kuvattu vastausten esiintyvyys kullakin vaihtoehdolla. Vastaajien $n=5$.

Kalastajat arvioivat myös tulevaisuudessa tärkeimpiä lajeja omassa kalastuksessaan. Kysymyksenasettelussa annettiin vaihtoehdoiksi viisi kalalajia (ahven, särki, kuore, siika ja kuore), joista tuli asettaa kolme keskeisintä lajia tärkeysjärjestykseen. Täplärapua ei huomioitu. Muikku, ahven ja särki koettiin merkittävimmiksi lajeiksi (kuva 3). 40 \% kalastajista arvioi, että täplärapu tulee olemaan jatkossa mainittuja kalalajeja tärkeämpi.

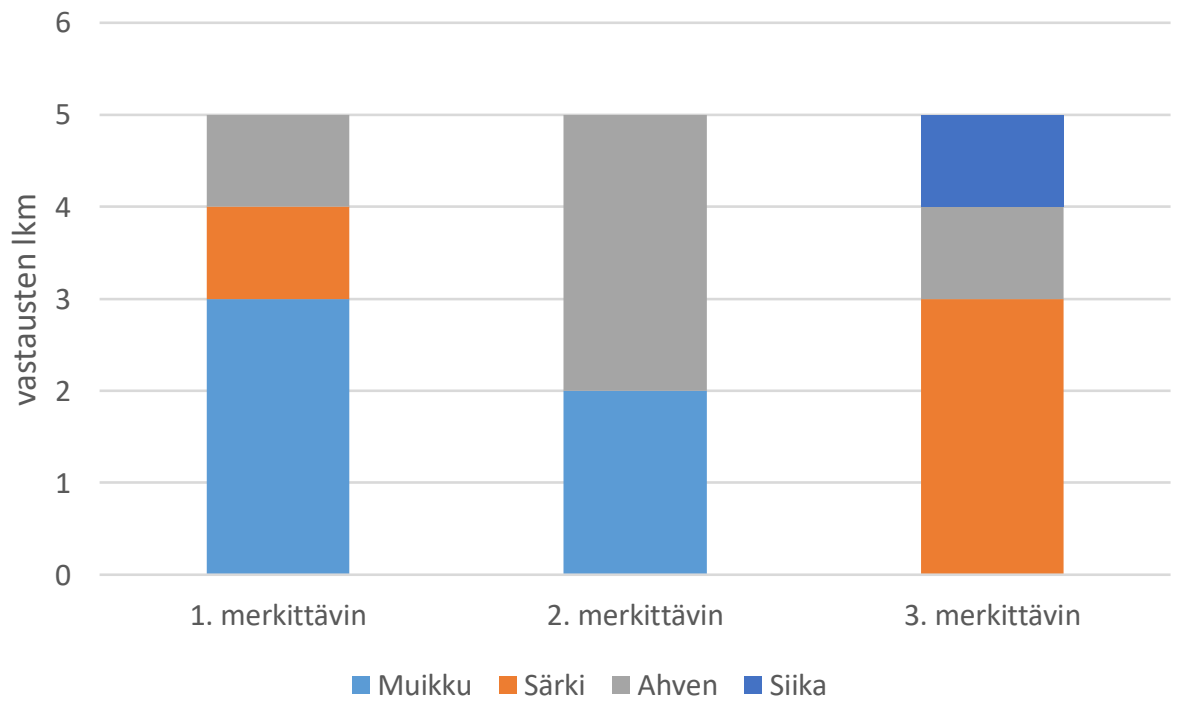

Kuva 3 Kalastajien arvio kalalajien merkittävyydestä ammattikalastuksessa tulevaisuudessa. Vastaajien n=5.

Kalastuksen sopivaa pyyntitasoa arvioitiin lajikohtaisesti ahvenen, särjen, kuoreen, siian ja muikun osalta. Ahvenen osalta kalastajien näkemykset olivat saman kaltaisia yhtä vastaajaa lukuun ottamatta, pyyntimääriä ei tulisi nykyisestä enää kasvattaa (kuva 4). Myöskään siian pyynnin ajateltiin olevan sopivalla, vaikkakin 
heikolla, tasolla. Muiden lajien kohdalla vastauksissa oli enemmän hajontaa. Kalastajien vastausten keskiarvo verrattiin myös Pyhäjärven kalastusalueen ilmoittamien vuosisaaliiden keskiarvoon vuosilta 2013-2017. Vastaajien vastausten keskiarvot olivat samaa suuruusluokkaa aiempiin saaliskeskiarvoihin verrattuna.

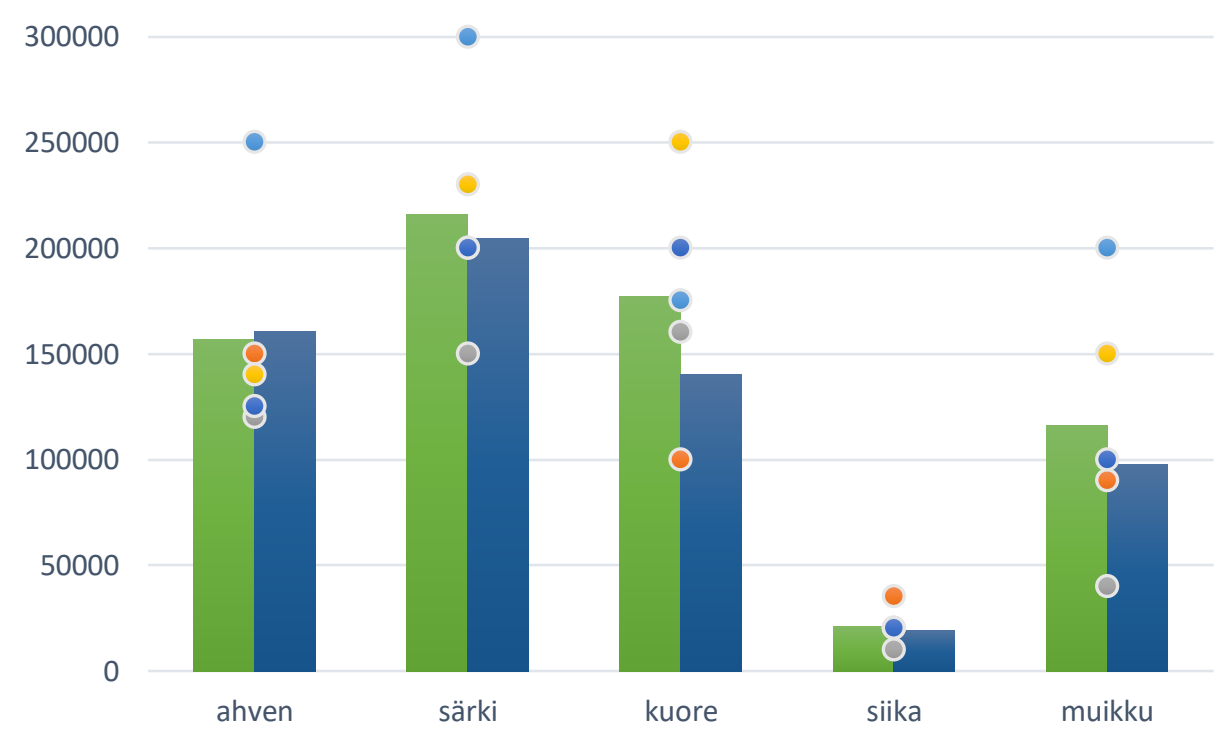

Kuva 4 Kalastajien arvio sopivasta pyyntitasosta kalalajikohtaisesti vuosittain. Vihreillä palkeilla on kuvattu vastausten keskiarvo. Pallot kuvaavat kalastajien yksittäisiä arvioita. Sininen palkki on arvio kunkin kalalajin vuosisaaliiden keskiarvosta vuosilta $2013-2017$. Kalalajien vuosisaaliit perustuvat Pyhäjärven kalastusalueen vuosisaalisarvioihin.

Ahven on vähentynyt. 0+-ikäryhmän muikku on vähissä.

Kuoretta on vaikea arvioida. Ehkä yksi vuosi tulee vielä hyvin kuoretta. Siika riippuu istutuksista. Ahven ei kovin äkkiä nouse. Muikkua pitäisi olla enemmän.

Särjessä (pyyntiä) hankaloittaa, kun kalaa pitäisi saada keväällä paljon kerralla, perkuun vuoksi. Joinakin vuosina särjen kutu menee kalastuksen kannalta liian nopeasti ohi säiden vuoksi.

Haastattelujen jälkeisissä keskusteluissa heinäkuussa 2018 useat kalastajat arvioivat muikun ja kuoreen kasvun pysähtyneen. Syyksi arveltiin poikkeuksellisen korkeaa järviveden lämpötilaa ja ravinnon puutetta.

\section{Ammattikalastuksen pullonkaulat}

\section{Tyytyväisyys vajaasti hyödynnettyjen kalalajien rahoitusmalliin}

Pyhäjärvellä vajaasti hyödynnettyjen kalojen pyyntiä on rahoitettu pitkään erilaisilla rahoituslähteillä. Keväällä 2018 saatiin kuitenkin tieto, että nykyinen, valtion budjetista rahoitettu hoitokalastus, päättyy Pyhäjärvellä. Hoitokalastuksen ulkopuolisen rahoituksen jatkuminen Pyhäjärvellä on jatkossakin epätodennäköistä. Kalastajilta kysyttiin tyytyväisyyttä hoitokalastuksen rahoitukseen tarkoituksena selvittää hoitokalastuksen ulkopuolisen rahoituksen merkitystä ja tarpeellisuutta niiden lajien osalta, jotka eivät tuota kalastajalle taloudellista arvoa. Kalastajien suhtautuminen viimeisimpään rahoitusmalliin oli vaihteleva:

Hoitokalastukseen tulisi olla tukea, rahan hakeminen on mennyt vaikeaksi. Byrokratiaa on paljon. Pyhäjärvelle pitäisi tulla enemmän tukea. Vähempiarvoisen kalan pyynti aiheuttaa kuluja kalastajalle.

Ei koske itseä kovin, mutta nuoremmilla hyvät saumat. 
Ei ole enää rahoitusta. Ei sillä (rahoituksen loppumisella) nyt suurta vaikutusta ole De Minimis-säädösten vuoksi.

Rahoitus pelasi ihan hyvin. Välillä oli rahojen saamisessa pitkä viive. Viive vaatii runsaasti puskuria.

\section{Vähempiarvoisten kalalajien pyynnin mahdollisuudet}

Vähempiarvoisen kalan pyynnin tulevaisuuden mahdollisuuksissa nousi esiin kuore.

Kuore voisi olla ainoa, jolla voisi olla todellisia mahdollisuuksia. Lahnaa menisi, muttei saa järkevää määrää. Voi joutua talvinuottaa eteläpäässä vetämään kaksi viikkoa putkeen, että osuu kohdalle kunnon satsi, jos silloinkaan.

Suutarissa voisi olla potentiaalia, mutta saaliit hyvin pieniä, menisi kaupaksi kyllä

Särkeä ja suutaria menisi, jos vaan tulisi. Kuore menisi eroteltuna. Kuore meni viime nuottakautena käytännössä kaikki. Pientä kuoretta ei ole paljoa tällä hetkellä järvessä

Kuore on hankala, koska kannat vaihtelevat niin paljon. Hinta on 35 senttiä/kg

Uusia tuotteita tulisi kehittää

Osakaskunnat voisivat osallistua hoitokalastuksen rahoitukseen esimerkiksi 10000 eur / osakaskunta / vuosi.

\section{Näkemyksiä Pyhäjärven kalastuksen kehittymiseen ja tulevaisuuteen}

\section{Kalastusmenetelmät}

Kalastajat arvioivat kalastusmenetelmien olevan Pyhäjärvellä hyvin nykyiseen tilanteeseen soveltuvia. Lupajärjestelmät koettiin osittain ongelmallisiksi. Ammattikalastuksen jatkumisen uhaksi nousi nuorten kalastajien riittävyys tulevaisuudessa.

Olen kannustanut nuoria kalastuksen kehittämiseen, jos aikoo elättää itsensä kalastuksella, täytyy pysyä ajan hermolla. Mutta kun ei ole nuoria. Vanhat eläköityvät. Rajoituksissa täytyisi olla tarkkana, ettei ylikalasteta. Rysäkalastus varmaa loppuu ja siirrytään troolaukseen. Tilanne on nyt hallinnassa pyydysten, pyyntiaikojen ja kalojen suhteen.

Menetelmät ovat nyt hyvällä mallilla. Kalastus ei kannata, jos ei pystytä kehittymään. Täytyy olla myös sopeutuva hallinto ja lupasysteemit.

Ikääntyminen on ongelmana, jotenkin täytyisi aktivoida nuoria.

Kalastuksen lupamaksut ongelmallisia, vaikeuttaa eritoten uusien kalastajien aloittamista.

Tuskin tulee äkkiä isompaa muutosta, kaikki on muuttunut kuitenkin radikaalisti viime vuosina (esim. avovesinuottaus). Kalatalousalue voi tuoda omat mausteensa, saa nähdä.

Verkot on siirtymässä historiaan.

Avovesikalastus lisääntyy suhteessa jään päältä tapahtuvaan pyyntiin.

\section{Tyytyväisyys kalastuksen säätelyyn}

Pyydysten määrä on oikealla tasolla. Muikkurysiä 4 / kalastaja on ok.

Jos hyvää muikkukantaa ei nyt tule, istutukset muikulle ja siialle tarpeen. Muikkua voisi istuttaa vaikka 10 miljoonaa (kpl/vuosi vastakuoriutuneina). 
Kalastusalueen johto suopea kalastukselle. Kulut suurentuneet aiempaan verrattuna, pitää saada enemmän kalaa suhteessa aiempaa. Kalastuksessa on suuntaus isot vehkeet ja harvemmat miehet. Ahvenen tilanne huolestuttaa, onko ylikalastettu jo?

Säätelyä ei ainakaan tule lisätä. Kalastajia on niin vähän, kalastusta ei tarvitsisi vaikeuttaa millään ylimääräisellä. Kalastajat loppuvat ennen kuin kalat. Kalakantojen säätely toimii markkinavetoisesti.

Avovesinuottaus tulisi rajoittaa yhteen yksikköön järvellä. Mökkiläiset on (avovesinuottauksesta) vihoissaan. Aiemmin talvinuottakaudella sai kalaa loppuun asti, nyt loppuu ennen aikojaan.

Nuoria pitäisi saada innostettua alalla, mutta ongelmana on palkan saaminen (epävarmuus). Vähempiarvoisten kalojen hintaa pitäisi saada ylös. Ostajia pitäisi olla enemmän, jolloin saadaan hintaan ylös. Yhtenä ongelmana, että kaikilla on kalaa monesti samaan aikaan. Maksut ongelmallisia esim. ympäristölupa ja tarkastukset, hygienia, kalastusalueen maksu ja osakaskunnan maksu. Ennen ei ollut mitään maksuja.

Ei tarvetta muutoksiin säätelyssä.

\section{Koulutustarpeet}

Valtaosa vastaajista ei kokenut tarvitsevansa lisäkoulutusta.

Pyydysmallisto ja tapa on erilainen kuin yleensä muualla. Ei siihen, mutta kalan käsittelyyn liittyen voisi olla tarpeita. Esim. Hätälä vaatii sertifikaatin vuoksi muun muassa saaliin jäitykset, sopivat pakkaukset ja jäljitettävyyden.

Ei tarvetta varsinaisesti, benchmarkkaus voisi kiinnostaa, jos on sopiva kohde

Ei mitään tarpeita. Ei kiinnosta reissut.

Nuottakamat voisi könttänä myydä parin viikon käyttöönottokoulutuksella, jonka pitäisin itse. Ei tarpeita koulutukselle.

Ei ole tarpeita koulutukseen.

\section{Myynti ja markkinointi}

Kiinnostusta keskitettyyn myyntiorganisaatioon tai muuhun vastaavaan toimielimeen kysyttiin. Valtaosalla vastaajilla kiinnostusta vaikuttaisi olevan, mutta järjestelyn toimivuuden suhteen syntyi epäilyjä.

Olen sitä ehdottanut, mutta yhteistyö ei oman nuottakunnan ulkopuolella tuskin onnistuu. Olemassa olevassa tilanteessa ei luultavasti onnistu. Ehkä tilanne muuttuu parin vuoden sisällä. Viiden vuoden kuluessa on jo ainakin 4 ukkoa nykyisistä ammattikalastajista eläkkeellä, sitten ei ole Säkylässä kuin yksi nuottakunta jäljellä. Kummallista, että nuorilla ole töitä. Ei pitäisi maksaa porukkaa kotiin. Täytyy hoitaa niin, että yksi hoitaa myynnin ja yksi laskut. Toiminnan täytyy olla avointa, kaikki tietää kuinka paljon maksaa. Ei tule riitoja.

Ei taida tulla mitään. Pienen ravun myynti organisaatio olisi tarpeen, niitä yli tarpeen. Isot menee kyllä.

Kai se hyvä olisi, mutta mennyt aika hyvin tällä systeemillä. Kalan ostajan kanssa on toiminut hyvin, hakee kaikki kalat satamasta ja rahat tulee ajallaan.

Olisi ehdottomasti parempi niille, jotka kalastavat. Ei tarvitsisi yksin soitella hädissään. Hinnat olisi samat tai paremmatkin. Kalat ei jäisi käteen. Välillä jouduttu ajamaan työpäivän jälkeen Juvalle tai Savonlinnaan. Seuraavana aamuna taas viideltä ylös ja järvelle. 
Ei kiinnosta

\section{Jalostukseen ja käsittelyyn liittyvät tarpeet}

Vain yksi vastaaja koki tarpeita perkuutöiden tehostamiseen.

Tarpeita on tässä eniten, perkuukone, kalan käsittelyyn tarvittaisiin saada tehokkuutta. Perattu kala tekee parhaiten kauppansa.

Ei tällä hetkellä järkeä investoida pakastusvehkeisiin, koska käyttökulut suuret.

Ei varsinaisesti. Kalojen lajittelukoneet voisi olla, mutta en tiedä onko saatavilla oikeasti toimivia malleja. Jalostukseen ei ole enempää haluja, koska teettää lisää töitä, mitä pyöreämpi sen parempi. Päivät ovat pitkiä muutenkin.

Kalustossa ei tarpeita. Kalaa odotetaan perattuna, mutta perkuuhommat järvipäivän jälkeen tekevät työstä raskasta. Hinta on tietysti tällöin korkeampi. Jalostukseen eli savustukseen ja perkaukseen täytyisi olla oma ryhmänsä, kun mennään perkaukseen ja savustukseen.

Jatkuvaa kehittämistä on ollut viime vuosina.

\section{Kiinnostus ja valmius kalastukseen muilla järvillä}

Köyliönjärvi voisi olla mahdollinen, esim. haukea. Hoitokalastusta voisi kyllä tehdä esim. Konsulttiapua varmaan voisi tarjota. Korvausta vastaa tietysti. Halukkaita voisi löytyä kyllä.

Ei ole kiinnostusta enää, Pyhäjärvellä toimitaan vastedes.

Ei ole tarvetta. Köyliönjärvi voisi olla ainoa tässä lähellä, kauhea työ siinä on kun pitää raijata kalustoa, jäitä yms. Punkalaitumen Vehkajärvellä ollaan käyty hoitokalastamassa, mutta iso on säätö. Paljon lisähommia. Menee useita päiviä itse kalastuksen lisäksi. Ihan ok tili siitä kylläkin tulee, mutta ei oikein kiinnosta. Ei ole aikomusta jatkaa Vehkajärven parissa, koska töitä on aivan riittämiin muutenkin.

Tarvis olla erilaiset vehkeet, pienemmät troolit. Vaatii investointia aika paljon. Ponttonialus, jossa perämoottori. Talvinuotta voisi olla käyttökelpoinen, mutta pitäisi olla matalampi nuotta, joka olisi monikäyttöisempi. Nykyinen pikkunuotta turhan raskastekoinen.

En enää, aikaisemmin olen tehnyt kyllä.

\section{Näkemyksiä hoitokalastuksen tarpeellisuuteen ja Pyhäjärven vedenlaatuun}

Nyt on ollut tosi tummaa. Tummuus keväällä lisääntynyt viime vuosina. Viime talvena ei näkösyvyys ei ollut yhtä iso kuin edellisenä. Näkösyvyys on pienempi jäiden lähdön jälkeen.

Aivan ruskeata vettä. Ei muuten valittamista. Aika hyvä kesälläkin ollut, jotain ainakin tehty. Kuore syötäväksi!

En osaa sanoa, ainoa helposti havainnoitava asia on kirkkaus ja siitä ei voi suoraan paljoa päätellä

Vesi on harvoin näin kirkasta tähän aikaan vuodesta. Hyvänä on pysynyt. Instituutti on tehnyt hyvää työtä. Palkkaus/korvaus on tässä tärkeää, että asioita tapahtuu.

Hoitokalastusta tarvitaan edelleen. 


\section{Vapaa sana}

Talvinuottakausi toi kalastajalle 80- ja 90-luvuilla riittävät tulot koko vuodelle (vrt. perus tehdastyöläisen vuoden palkka). Nyt tilanne on tyystin eri. Ravustus ja rysät ovat tärkeämmässä roolissa. Talvinuottakausi on lyhentynyt ja muikkua on vähemmän. Tänä vuonna (2018) talvinuottakaudelta tuli nelisen tonnia (eur) mieheen.

Kalastajien määrä tippuu tulevaisuudessa. Jotain halukkaita voisi olla, mutta siihen synnytään. Nuorella on edessä kovat investoinnit heti alkuun. Voi olla myös lainan saamisessa ongelmaa. Nuottaosuus maksaa luokkaa 20000 eur. Kalastuksen aloitusinvestoinnit ympärivuotiseen kalastukseen maksavat yht. 70 100000 eur henkeä kohti. Haasteita ammatissa on: Saaliit vaihtelevat, pitkät rospuuttoajat, pitkiä kausia ilman tuloa, epävakaus, yksityisyrittäjäksi ryhtyminen. Myös verotus pitää muistaa hoitaa kunnolla. Ammattikalastajalla on tänä päivänä hyvin vähän mahdollisuuksia kiertää veroja.

Uusia vesiensuojeluprojekteja rehevöitymisen pysäyttämiseksi tulisi käynnistää. Kasvillisuuden poistaminen ja ruohottumisen estäminen virtausolojen parantamisella olisi yksi tärkeä asia, johon tulisi kiinnittää huomiota. Yksi toimenpide voisi olla Paskalonlahdesta tehtävä kanava Rantasuon rantaan, jolla virtauksia saataisiin parannettua. Omarahoitusta löytyisi todennäköisesti ranta-asukkaista.

1971 viimeiset ankeriaat Lehmuunnokasta. Ankeriaat puulaatikossa. $25 \mathrm{~kg}$ lasiankeriaita. Samoihin aikoihin rakennettiin Pihlavan silta ja alueella virtaus heikkeni merkittävästi. Paskalon nokan juuren tehtiin virtausaukko. Seurakunta antoi luvan.

Pintapyydysten päälle ajellaan, rysiä menee rikki. Pitäisi olla aina tiedotus kalastuskisojen yms. tapahtumien yhteydessä. Pyydykset eivät ole merkityillä väylillä. Veneilijöiden kuuluisi kunnioittaa vähimmäisetäisyysmääräyksiä. Kalastuksen valvontaa pitäisi lisätä ravustusaikaan.

Ahvenia ei otettu saaliiksi 10-15 v. sitten. Ensin aloitettiin ahventen rysäpyynti. Nyt edelleen tehostettu. Haukea kuoli kymmeniä tuhansia kiloja viime vuonna (2017), läikkätauti.

Kalastajien väheneminen ei ole hyvä. Lajit monipuolisesti hyötykäyttöön! Kyllä kalakannat palautuvat.

Suurin uhka on särjen jalostuksen loppuminen Säkylässä (Kolvaan kala), mutta ei ole näköpiirissä.

70 luvulla, tuli siikaa niin paljon, että joskus joutui leikkaamaan puukolla perän auki, koska ei mennyt kaupaksi...

Kiiski on vähentynyt rajusti, johonkin on kadonnut. Jaksaminen voi olla joskus heikkoa, varsinkin jos peräpussissa ei ole tavaraa.

Madekausi on mennyt tosi lyhyeen, aiemmin kesti 1-1,5 kk, nyt made on matalassa ehkä pari viikkoa. 
Liite 1 Haastattelulomake

Kalastajahaastattelut kesäkuu, 2018

Kohderyhmä: Pyhäjärven ammattikalastajat

Keskeisimmät kalastusmuodot, osuus kalastuksesta saatavasta toimeentulosta:

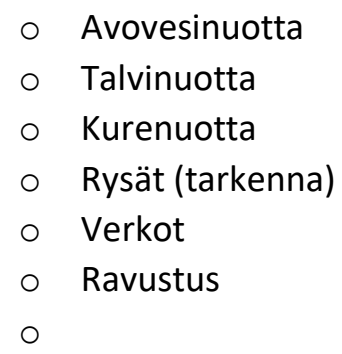

Keskeisimmät kalalajit, osuus toimeentulosta:
- Muikku
- Siika
○ Särki
- Ahven
- Made
○ Kuore
○ Muut:

Ammattikalastuksen pullonkaulat, mitkä seikat jarruttavat:

Vähempiarvoisen kalan pyynnin tulevaisuus:

- rahoitus, tyytyväisyys nykyiseen malliin:

- mahdollisuudet:

Näkemys Pyhäjärven kalastuksen kehittymiseen ja tulevaisuuteen

- kalastusmenetelmät:

- Olisiko kalastuksen säätelyä muutettava jollain tavalla, millä ja miksi?

- Koulutustarpeet? (turvallisuus, menetelmät, tekniset sovellukset ym.) 


\section{Sopivan saalistason arviointi}

Kuinka paljon mitäkin kalalajia voisi mielestänne pyytää? Merkitse kuviin mielestänne sopiva taso viivalla, halutessasi voit antaa vaihteluvälin sopivalle tasolle.

Minkä kalalajien arvelette olevan tärkeimpiä tulevaisuudessa omassa kalastuksessanne? Merkitse kolme tärkeintä kuviin numeroin $(1,2,3)$.
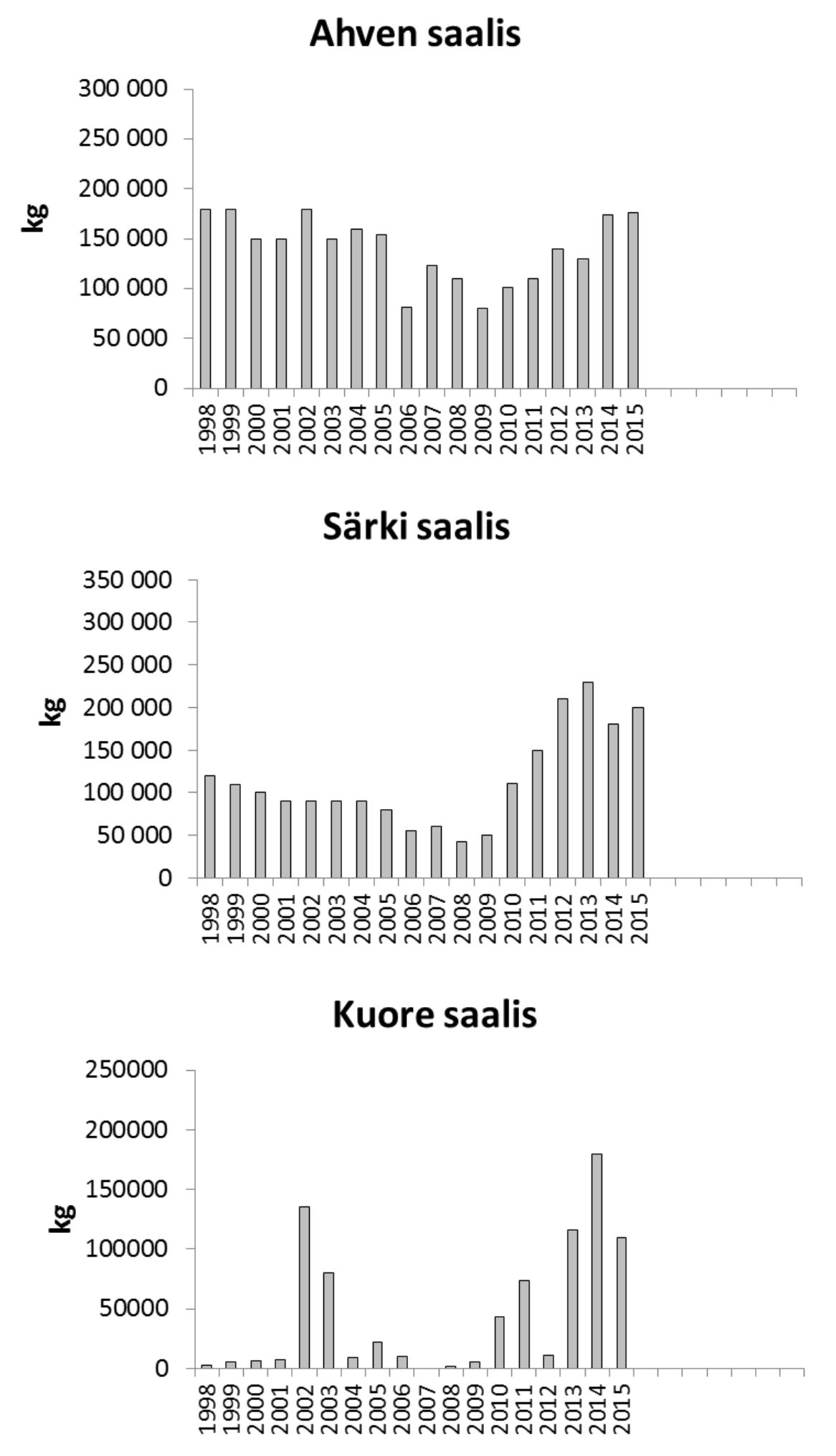


\section{Siika saalis}

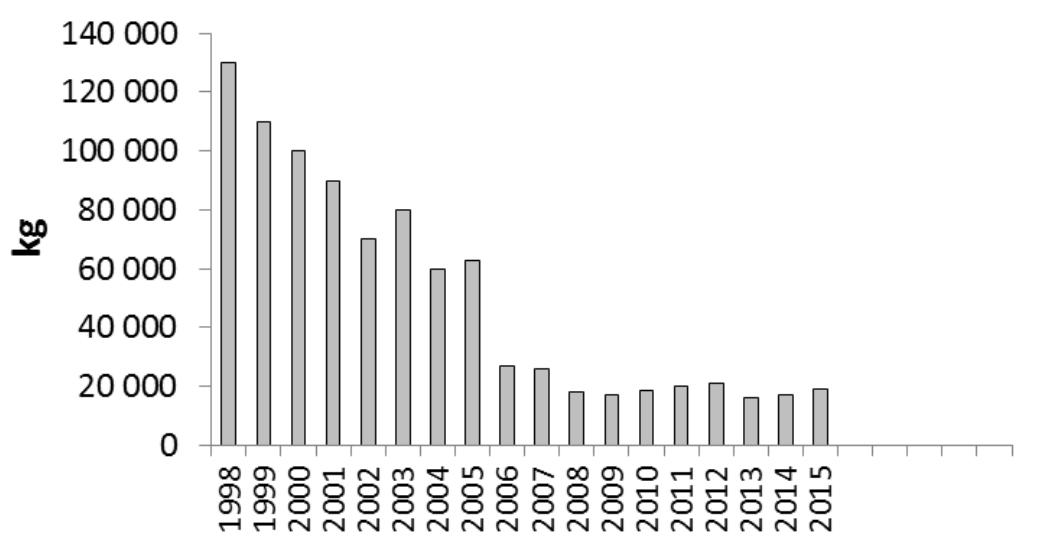

\section{Muikku saalis}

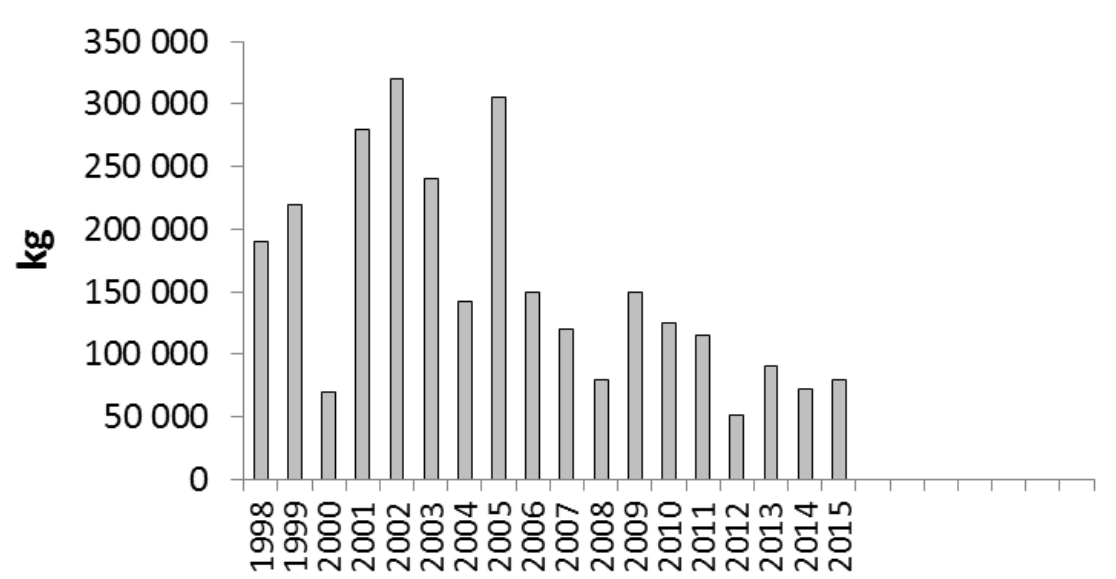

Saaliin myynti ja markkinointi

- keskitetty myyntiorganisaatio tms. toimielin kiinnostaako?

- voiko olla osuuskunta?

Käsittely / jalostus, mitä tarpeita?

- Tilat, koneet?

Mitä mieltä Pyhäjärven vedenlaadusta? Tarvitaanko hoitokalastusta?

- ELY-tuen toimivuus? 
Olisitko valmis kalastamaan muilla järvillä?

- Millä edellytyksillä? Kuinka kaukana?

Muut terveiset ja mietteet 